\title{
Moradebrichthys vilasecae gen. et sp. nov., a new perleidid (Actinopterygii: Osteichthyes) from the Middle Triassic of Catalonia (NE Iberian Peninsula)
}

\author{
Joan Cartanyà, Josep Fortuny, Arnau Bolet, and Ruben Garcia-Artigas
}

With 14 figures and 1 table

\begin{abstract}
A new actinopterygian, Moradebrichthys vilasecae gen. et sp. nov., from the Middle Triassic (Late Ladinian) of Móra d'Ebre-Camposines (Catalonia, NE Iberian Peninsula) is erected on the basis of several, almost complete, articulated and well preserved specimens. It is referred to the controversial family Perleididae based on the presence of a combination of features such as paried nasals, presence of rostral, vertical suspensorium, absence of interopercle, lack of coronoid in the mandible, basal and fringing fulcra on fins developed to different extents and an almost symmetrical caudal fin with epaxial fin rays. Comparisons to other well-known taxa usually assigned to the Perleididae family reveals that the new taxon presents many similarities with the genera Perleidus, Peltoperleidus, Aetheodotus and Meridensia, rather than other perleidids. Moreover, additional morphological characters, not shared with any of these genera are: a big half moon shaped infraorbital- 2 and one elongate infraorbital-1, a narrow vertical preopercle with a prominent and pointed anterior maxillary process, a dentary covered by horizontally arranged ridges, a very big opercle and a much smaller subopercle, and the high level of lepidotrichia branching in the caudal fin. A comparison of Catalan Middle Triassic actinopterygian assemblages with other ones from Central European basins of coeval age (particularly Italian and Swiss localities) suggest some faunal similarities, being of special interest the potential correlation with the Besano Formation.
\end{abstract}

Key words: New taxon, actinopterygian, Ladinian, Middle Triassic, Móra d'Ebre, Catalonia.

\section{Introduction}

The Triassic actinopterygian assemblages recovered in the Iberian Peninsula are scarce and usually presenting poorly preserved specimens, with the notable exception of the Catalan and Pyrenean basins (NE area) where some localities have yielded an important paleontological record. One of these localities is placed in the Móra d'Ebre - Camposines area (see ForTUNY etal. 2011 for a review of other localities) (Fig. 1). This area has been historically studied since the middle 19th century due to the rich palaeontological outcrops discovered, including ammonoids, bi- valves, brachiopods, echinoderms and thylacocephalans (Verneuil 1854; D'ArChiach 1860; Neumayr 1868; Mallada 1889; Llopis Lladó 1947; Virgili 1958; Calzada \& Mané 1993). Wurm (1913) was the first to report the presence of actinopterygian remains in the Triassic outcrops of Móra d'Ebre. More recently, some works deepened on the geology of the Triassic outcrops of southern Catalonia, providing a general framework of the stratigraphy and sedimentology of this area (Robles \& INIESTA 1977; Guimerà 1984; Guimerà 1988; TeiXell 1986; CALvet \& Tucker 1988; Calvet et al. 1990; Calvet \& Marzo 1994). The work of Mirabal (1998) is of 


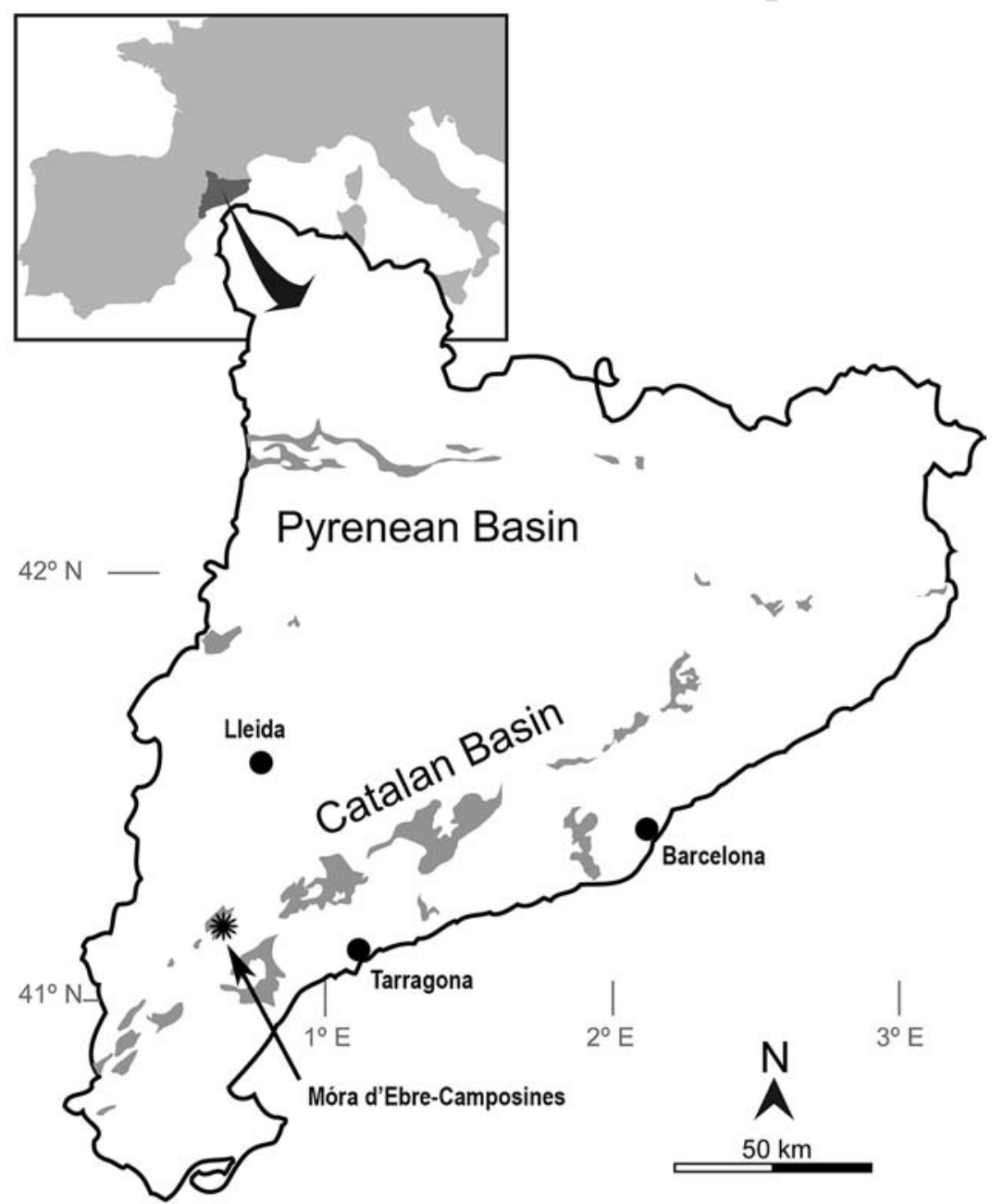

Fig. 1. Geographical situation of the studied locality.

special interest because he described the geology and paleontology of Móra d'Ebre-Camposines outcrops along the road from Móra d'Ebre city to Sant Jeroni chapel with a first major reference to the actinopterygian remains. It should be noted that during the first years of the $20^{\text {th }}$ century different quarries existed in the nearby area of Móra d'Ebre. Lastly, ForTunY et al. (2011) provided a comprenshive review of the Triassic vertebrates from the Iberian Peninsula, reporting the presence of new articulated and well preserved specimens from Móra d'Ebre-Camposines area, with a preliminar description of new perleidiform remains.

Taxa classified as perleidiforms are known from several widely distributed localities of the European Middle Triassic, and they are specially wellknown from the Late Ladinian of Monte San Giorgio (Switzerland and Italy), but also from the Carnian of Raibl/Cave del Predil near Udine (Italy) (GRIFFITH 1977; BÜRGIN 1992; LOMBARdO 1997; MUtTER 2002; Mutter \& Herzog 2004; Rusconi et al. 2007). The monophyly of 'Perleidiformes' has been largely discussed and it is out of scope of the present paper. In the Iberian Peninsula in general, and in the Catalan Basin in particular, the 'perleidiforms' are known from the classical outcrops of Alcover, placed about $100 \mathrm{~km}$ to the north of Móra d'Ebre-Camposines outcrops, representing the first remains of the group described from the Triassic of the Iberian Peninsula (Beltan 1972) (see VIA-BoAda et al. 1977 for a review). The 'perleidiform' genera known from the Alcover outcrops are: Colobodus, Perleidus, Ctenognatichthys, Peltoperleidus, and Luganoia(Beltan 1972; Beltan 1975; Beltan 1984; Cartanyà 1999). 
The main goal of this work is to describe the most abundant taxon present at the Móra d'EbreCamposines outcrop and to discuss the systematic affinities of this new taxon with other 'perleidiforms' recovered in the Alcover outcrops, in the Alpine Triassic (e.g., Meride, Monte San Giorgio, Besano) and in contemporaneous outcrops in the southern part of China (e.g., Yunnan, Anhui, Guizou).

\section{Geological context}

The Móra d'Ebre-Camposines outcrop yielding actinopterygian remains is situated between the Móra d'Ebre city and Sant Jeroni Chapel (Ribera d'Ebre, Catalonia, Spain, NE Iberian Peninsula), and belongs to the Baix Ebre - Priorat domain (CAlvet et al. 1990) of the Catalan Basin (Fig. 1).

The Triassic rocks of the Iberian Peninsula are subdivided on the Triassic facies: Buntsandstein, $\mathrm{Mu}$ schelkalk and Keuper. These facies are not considered time intervals, as the development of the different rift systems in central and Western Europe was not coeval, causing diachronous facies changes (López-Gómezet al. 2002; Mercedes-Martinetal. 2013).

The Móra d'Ebre-Camposines outcrops lithologically correspond to the Upper Muschelkalk facies. The Baix Ebre - Priorat domain is divided into five stratigraphic units, from older to younger: Calcàries i/o dolomies de Rojals ("Limestones and/or dolomites of Rojals"); Calcàries bioturbades i dolomies de Benifallet ("Bioturbed limestones and dolomites of Benifallet"); Calcàries i/o dolomies de Rasquera ("Limestones and/or dolomites of Rasquera"); Calcàries, dolomies i margues de Tivissa ("Limestones, dolomites and marlstones of Tivissa"); Dolomies, lutites i bretxes de Capafonts ("Dolomites, lutites and breccias of Capafonts") (CALVET \& RAMON 1987; Calvet et al. 1987).

The first sequential analysis of the Middle Triassic in the Catalan basin was made by CALvet et al. (1990), who described two depositional sequences. The first sequence (SD1) includes Anisian lithostratigraphic units from the Upper Buntsandstein to the Lower Muschelkalk facies, whereas the second sequence (SD2) includes Ladinian units from the middle to the Upper Muschelkalk facies (Fig. 2). Posteriorly CALveT \& TucKer (1995) proposed the division of the SD2 in two Ladinian depositional sequences: L1 (lower Ladinian) and L2 (upper La- dinian). The Móra d'Ebre-Camposines locality belongs to the Calcàries i/o dolomies de Rasquera unit, SD2-L2, dated as Late Ladinian due to presence of the bivalve Daonella lommeli (VIRGILI 1958; MárQUEZ 1983), the conodonts Sephardiella mungoensis and Pseudofurnishius murcianus and the ammonoids Protachyceras steinmanni, Protachyceras hispanicum and Hungarites pradoi (VIrgiLI 1958). The Calcàries i/o dolomies de Rasquera unit consists of five lithofacies (CAlvet \& Tucker 1988), from base to top: 1) Marlstone-shale facies up to $7 \mathrm{~m}$ thick. The colour is generally grey-green to brown. Bedding is poorly defined, but locally there is a millimetre-scale paper lamination. Bioturbation is generally absent and fossils are rare. 2) Marlstone with thin-interbedded limestones faces. The thickness of the grey marlstone are few centimeters and of the limestones about $0.01-0.05 \mathrm{~m}$. The thin-bedded limestones are, in general, laminated lime mudstone, with scarce thin-shelled bivalves (Daonella) concentrated along some laminae. These facies are interpreted as corresponding to the distal deep ramp. 3) Thin-bedded limestone facies with 0.3 to $6 \mathrm{~m}$ thick, with intercalations of thin marlstones and millimetre-thick dolomitic partings. These facies have been interpreted as intermediate deep ramp deposits. 4) Thick-bedded wakestone facies. The thickness varies from 0.3 to $4 \mathrm{~m}$ and the grey wakestone beds are 0.2 to $1 \mathrm{~m}$ thick. The wakestones contain thinshelled bivalves, echinoderms and ostracods. These facies have been interpreted as proximal deep ramp. 5) Packstone-coquina facies up to $0.5 \mathrm{~m}$ in thickness. The macrofaunal assemblage includes bivalves, ammonoids, Tubiphytesand vertebrate remains. These facies are interpreted as the shallowest-water facies of the cycles (CALvet \& TUCKer 1988).

\section{Material and methods}

The studied material in part belongs to a historical collection, but also from the unique systematic excavations performed in the area in 2011 and 2017. The historical material was collected in the last years of the seventies by Rafel Mirabal and is stored at the Centre d'Estudis i Recursos del Migjorn de Catalunya (Montblanc, Catalonia, Spain), with the exception of a jaw fragment assignable to Saurichthydae deposited in the collections of the Museu Geològic del Seminari Conciliar de Barcelona. The material recovered during two recent excavations, in 2011 and 2017, includes approximately 500 remains, mainly corresponding to actinopterygians (about 300 remains), but also to ammonoids, bivalves, thylacocephalans, and other invertebrate groups. Most of the material is referable to the new taxon herein reported, although other specimens, currently under 


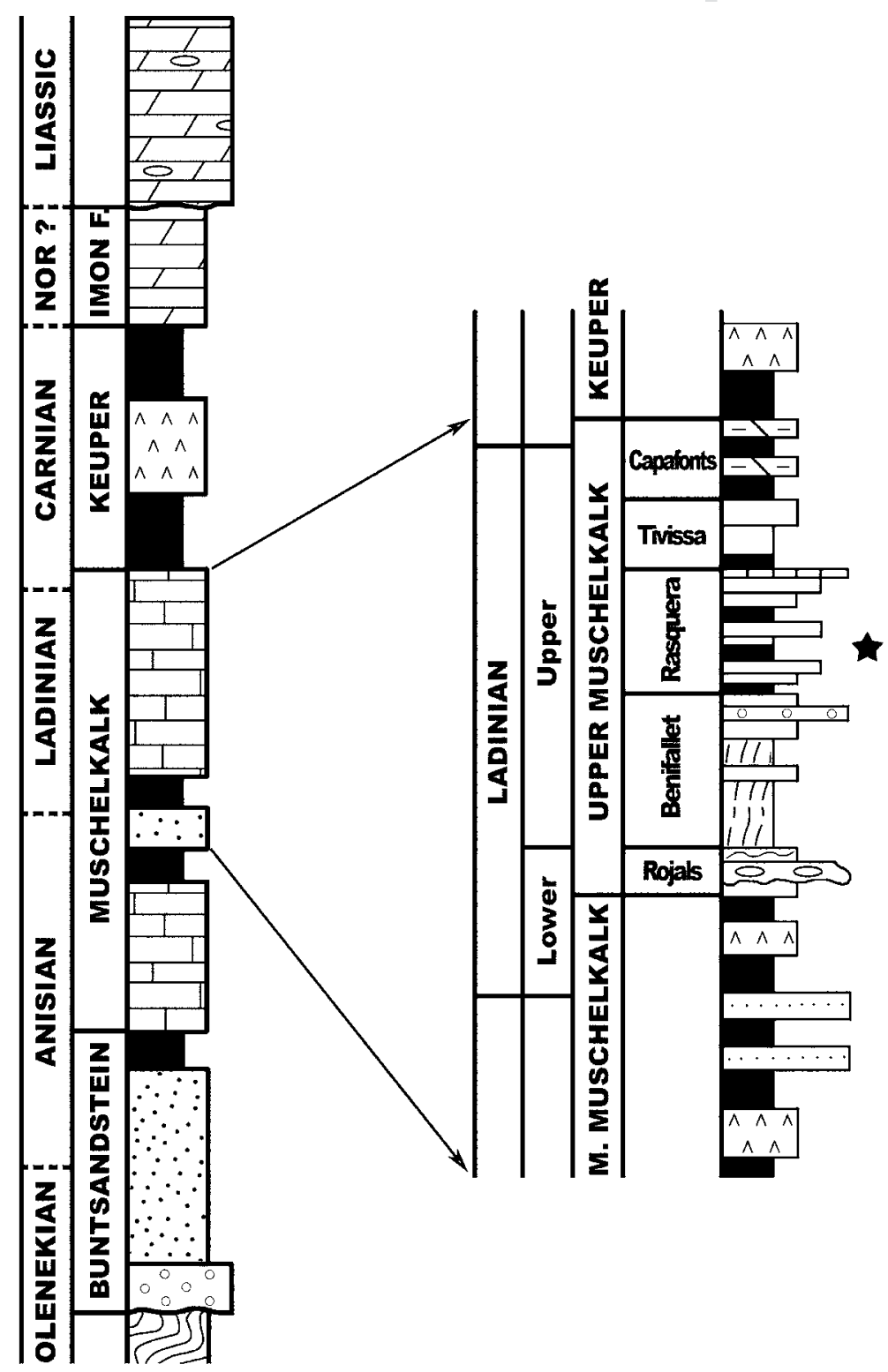

Fig. 2. Stratigraphy and sequential analysis of the upper Muschelkalk facies in the Baix Ebre-Priorat Domain. Modified from CALveT et al. (1990).

preparation, present a different morphology. All the specimens coming from the excavations of 2011 and 2017 are stored at Institut Català de Paleontologia Miquel Crusafont collections (Sabadell, Catalonia). The studied material includes around 180 specimens referable to the new taxon, 14 of which are almost complete, articulated and well preserved (Fig. 3).

The specimens have been prepared by mechanical methods and chemically with formic acid (5\% in vol.). The photographs and measurements were taken with a stereomicroscope Leica MZ-16A. The line drawings were carried out with Adobe Photoshop and Illustrator CS6 softwares. In these drawings the solid lines represent the preserved bone margins and the striped lines are used for inferred bone margins (Fig. 4).

Institutional abbreviations: CERAM, Centre d'Estudis i Recursos del Migjorn de Catalunya, Montblanc, Catalonia, Spain; IPS, Institut Català de Paleontologia Miquel Crusafont, Sabadell, Catalonia, Spain; PIMUZ, Paläontologisches Institut und Museum der Universität Zürich, Switzerland. 
Anatomical abbreviations: ad, adnasal; aic, anterior infraorbital canal; anam sbo, anamestic suborbitals; ang, angular; ant, antorbital; apl, anterior pit line; b.f., basal fulcra; br, branchiostegal rays; clt, cleithrum; d.s., dorsal scute; dent, dentary; dhy, dermohyal; dic, dorsal infraorbital canal; dpt, dermopterotic; dsph, dermosphenotic; ethc, ethmoidal commissure; exsc, extrascapular; f.f., fringing fulcra; fr, frontals; ifo, infraorbital; l.epx, epaxial procurrent lepidotrichia; mpl, middle pit line; mx, maxilla; na, nasal; op, opercle; orb, orbita; pa, parietal; pcl, postcleithrum; pcl.s., postcleithral scale; pf, pectoral fin; pit gr., pit groove; pmx, premaxilla; pop, preopercle; ppl, posterior pit line; prl, profundus line; pro, postrostral; ptp, posttemporal, ro, rostral; sbo, suborbital, sorb, supraorbital; sc, sensory canals; sclt, supracleithrum, soc, supraorbital canal; sop, subopercle; sr, skull roof; v.s. ventral scute.

\section{Systematic paleontology}

\author{
Class Osteichthyes HuXLey, 1880 \\ Subclass Actinopterygii COPE, 1887 \\ Order 'Perleidiformes' BERG, 1937 \\ Family Perleididae Brough, 1931 \\ Genus Moradebrichthys nov.
}

Etymology: The genus name refers to the locality Móra d'Ebre-Camposines (Ribera d'Ebre, Catalonia, Spain, NE Iberian Peninsula), where the remains were collected.

Type species: Moradebrichthys vilasecae sp. nov., monotypic.

Diagnosis: Perleidid actinopterygian characterized by the following unique combination of characters: one elongate infraorbital-2 and one big infraorbital-1; a narrow vertical preopercular with a prominent and pointed anterior maxillary process; a mosaic of suborbitals; maxillary with slightly concave dorsal border, expanded posteriorly; dermohyal (antopercular) absent; low, rounded teeth on the pterygoids and on the prearticular; dentary covered by horizontally arranged ridges, caudal fin moderately forked; scales and dermal bones smooth, or with a weak ornamentation.

Age: Late Ladinian (Middle Triassic).

\section{Moradebrichthys vilasecae sp. nov.} Figs. 3-14

Etymology: Dedicated in memoriam to TONI VILASECA for his efforts on the paleontological research of the Alcover area and other locations of Conca de Barberà in close collaboration with the first author, and for his enthusiasm in the popular dissemination of paleontology.

Diagnosis: As for the genus.
Holotype: CERAM R001: almost complete, well-preserved specimen of $55 \mathrm{~mm}$ of standard length.

Paratypes: IPS89145, IPS89171, IPS89202, IPS109792, IPS109801, CERAM R002b, CERAM R004, CERAM R007, CERAM R010, CERAM R020, and CERAM R030.

Other material: CERAM R002a, CERAM R003, CERAM R012, IPS88993, IPS88995-IPS89006, IPS89009, IPS89010, IPS89014-IPS89016, IPS8908, IPS89019, IPS89021-IPS89025, IPS89027-IPS89029, IPSA89032, IPS89034, IPS89036, IPS89041， IPS89043-IPS89046, IPS89048-IPS89050, IPS89052-IPS89059, IPS89061IPS89069, IPS890721-IPS89073, IPS89075-IPS89080, IPS89082, IPS89082, IPS89083, IPS89091, IPS89092, IPS89094-IPS89096, IPS89098-IPS89106, IPS89108, IPS89109, IPS89111-IPS89119, IPS89121, IPS89123, IPS89124, IPS89126-IPS89129, IPS89131-IPS89141, IPS89143, IPS89146-IPS89149, IPS89151-IPS89159, IPS89162, IPS89162, IPS89165-IPS89170, IPS89172, IPS89173, IPS89175, IPS89176, IPS89178-IPS89181, IPS89185, IPS89190, IPS89197-IPS89201, IPS89203IPS89205, and IPS89206.

Type locality: Móra d'Ebre-Camposines: Sant Jeroni, Móra d'Ebre (Catalonia, NE Iberian Peninsula).

Type horizon: Uppermost Rasquera Unit, Upper Ladinian (Middle Triassic).

Description: Measurements for the 16 best preserved specimens of Moradebrichthys vilasecae are given in Table 1. Most of specimens have a partially disarticulated skull and some degree of deformation. In these cases it is not possible to take precise measurements and it is necessary estimate some morphometric proportions (in brackets in Table 1).

General morphological features. Moradebrichthys vilasecae has a blunt snout and a fusiform body. All complete specimens are of small size, up to $55 \mathrm{~mm}$ in standard length (SL). The skull is relatively large, approximately as deep as the body and the skull length represents about $25-30 \%$ of the SL. The preorbital length represents a $50 \%$ of the orbital length and the preorbital length a $25 \%$ of the postorbital length.

The orbital surface is moderately large, its diameter representing about $25 \%$ of the head length. The maximum body depth is no longer than $25 \mathrm{~mm}$. The ratio body length/body depth is approximately 3 . The dorsal fin is triangular and located a little far posteriorly, and its origin is posterior to that of pelvic fins, betwen the pelvic and anal fins, but more proximal to the anal fin. The tail is deeply forked and equilobated (Figs. 3, 4).

Skull roof, braincase and snout. The skull roof is incompletely preserved in all the specimens, but some comments can be made based on characters observed in different specimens (in particular CERAM R002b, CERAM R007, IPS-89145 and IPS-89202) (Figs. 5-8). Each side of the skull roof is formed by two bones. The anterior part is 


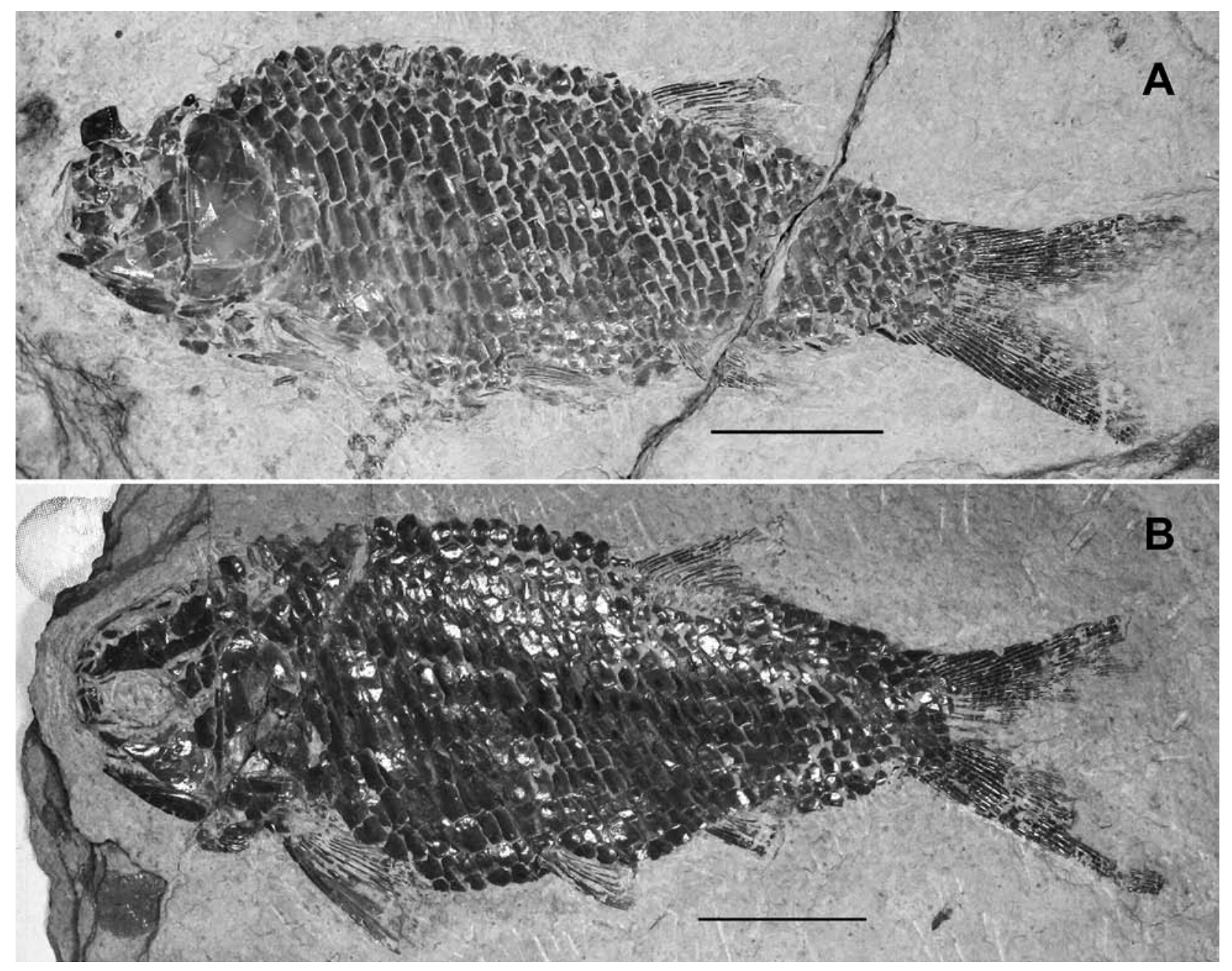

Fig. 3. Moradebrichthys vilasecae gen. et sp. nov. Lateral view of total body. A - CERAM R001, holotype; B - CERAM R007, paratype. Scale bar equals $1 \mathrm{~cm}$.

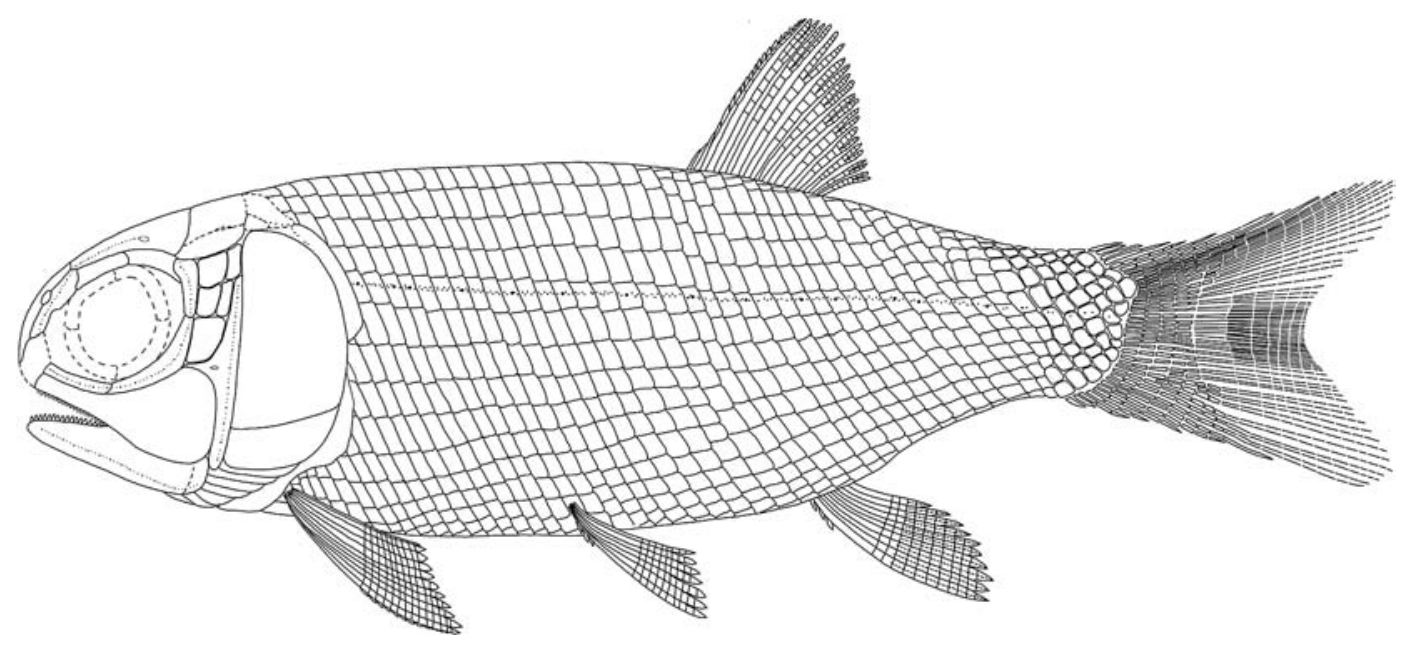

Fig. 4. Moradebrichthys vilasecae gen. et sp. nov. Idealized restoration of the skeleton. 
Table 1. Morphometric and meristic data of the specimens described. Abbreviations in upper row, left to right: SL, total length; HL, head length (from anterior border of snout to posterior border of cleithrum); PDD, predorsal distance (from anterior border of snout to anterior insertion of dorsal fin); PCD, prepectoral distance; PVD, prepelvic distance; PAD, preanal distance; CPH, caudal peduncle height; $\mathbf{M B H}$, maximum body height; $\mathbf{H H}$, head height (from highest point of dermopterotic-postparietal to lowest point of branchiostegal rays). Brackets indicate that the measure is an estimate or that the account is made for a poorly preserved structure. All measurements are in millimeters.

\begin{tabular}{llllllllll}
\hline & SL & HL & PDD & PCD & PVD & PAD & CPH & MBH & HH \\
\hline CERAMR001 & 54.5 & 13.5 & 35.75 & 12.5 & 27.5 & 37 & 7.5 & 20 & 13 \\
CERAMR002a & $(46.9)$ & $(13.1)$ & $(34)$ & $(15.5)$ & $(26.6)$ & $(35.11)$ & $(6.66)$ & 20 & $(17.77)$ \\
CERAMR002b & 48.72 & 14.28 & 32.14 & 13.09 & 27.38 & 40 & 7.14 & 20.23 & 13.80 \\
CERAMR003 & $(48.5)$ & - & $(31.5)$ & - & $(25)$ & $(36.4)$ & 9.52 & 23.86 & - \\
CERAMR004 & - & 12.5 & & - & - & - & - & - & 10.86 \\
CERAMR007 & 51.25 & 13.75 & 33.75 & 12.5 & 2.75 & 37.5 & 7.5 & 22.5 & 16.25 \\
CERAMR010 & - & 13.55 & 30.5 & 11.01 & - & - & - & - & 13.55 \\
CERAMR012 & - & - & - & - & - & - & 5.76 & - & - \\
CERAMR020 & - & - & - & - & - & - & 6.12 & 18.36 & - \\
CERAMR030 & 49.05 & 12.85 & 36.9 & 13.09 & 26.19 & 36.9 & 7.14 & 19.04 & 13.57 \\
IPS89145 & - & 12.5 & - & - & - & - & 6.07 & 17.86 & 12.5 \\
IPS89166 & 44.57 & 10.86 & 28.26 & 10.87 & 23.91 & 31.52 & 6.08 & 16.30 & 12.04 \\
IPS89190 & 51.25 & 13.75 & 37 & - & 26.25 & 37.5 & 6.5 & 21.25 & 13.75 \\
IPS89202 & - & 10.83 & - & 10.5 & 17.5 & - & - & 15 & 11.66 \\
IPS109792 & 42.15 & 11.65 & 26.21 & 12.4 & 22.95 & - & 5.10 & 17.57 & 12.61 \\
IPS 109801 & 52.20 & 14.9 & 32.6 & 14.3 & 27.65 & - & 6.10 & 21.30 & 15.20 \\
\hline
\end{tabular}
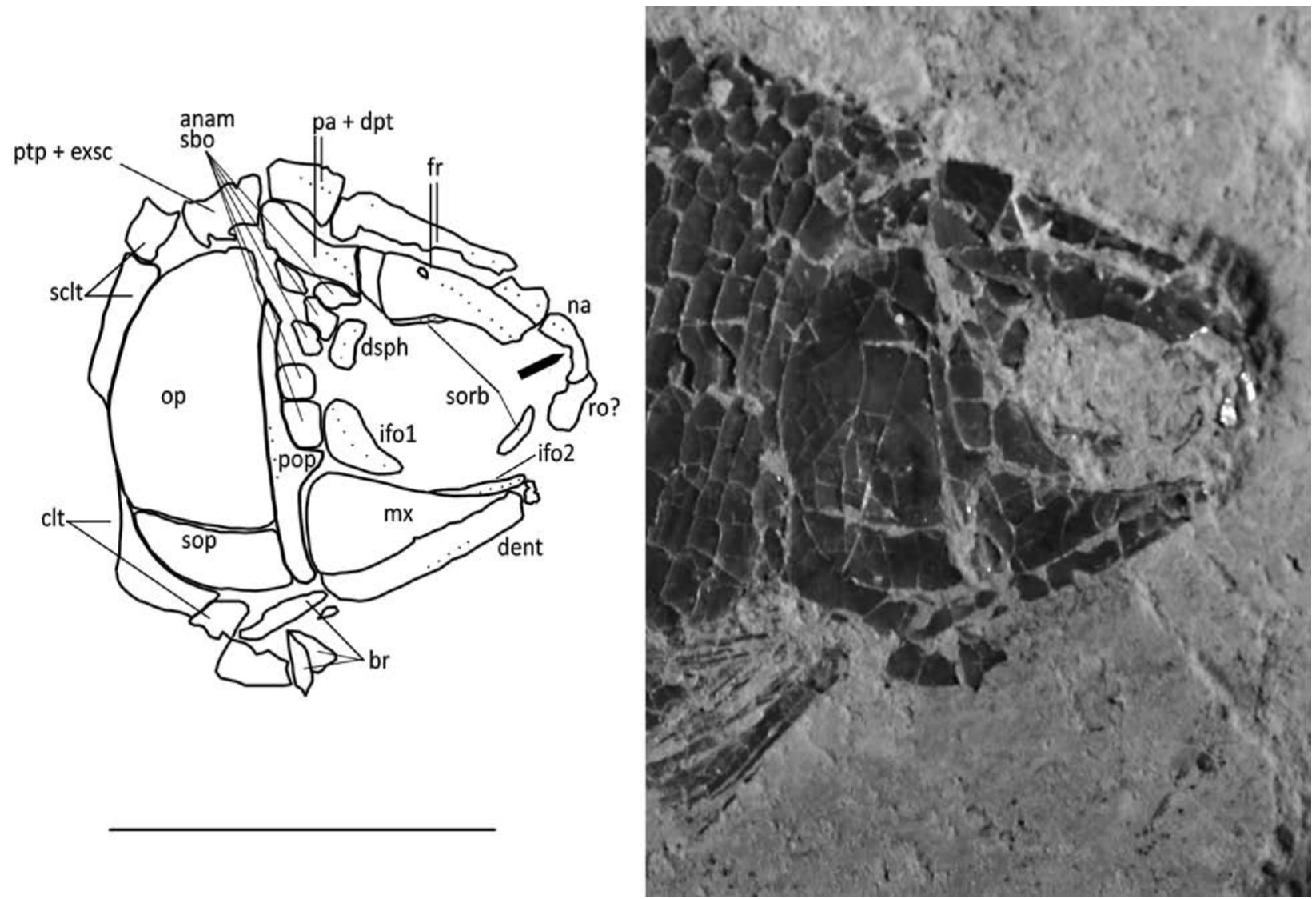

Fig. 5. Moradebrichthys vilasecae gen. et sp. nov. Skull (IPS89145, paratype). Scale bar equals $1 \mathrm{~cm}$. Note the arrow noting the presence of a small notch at the anterior nostril. 

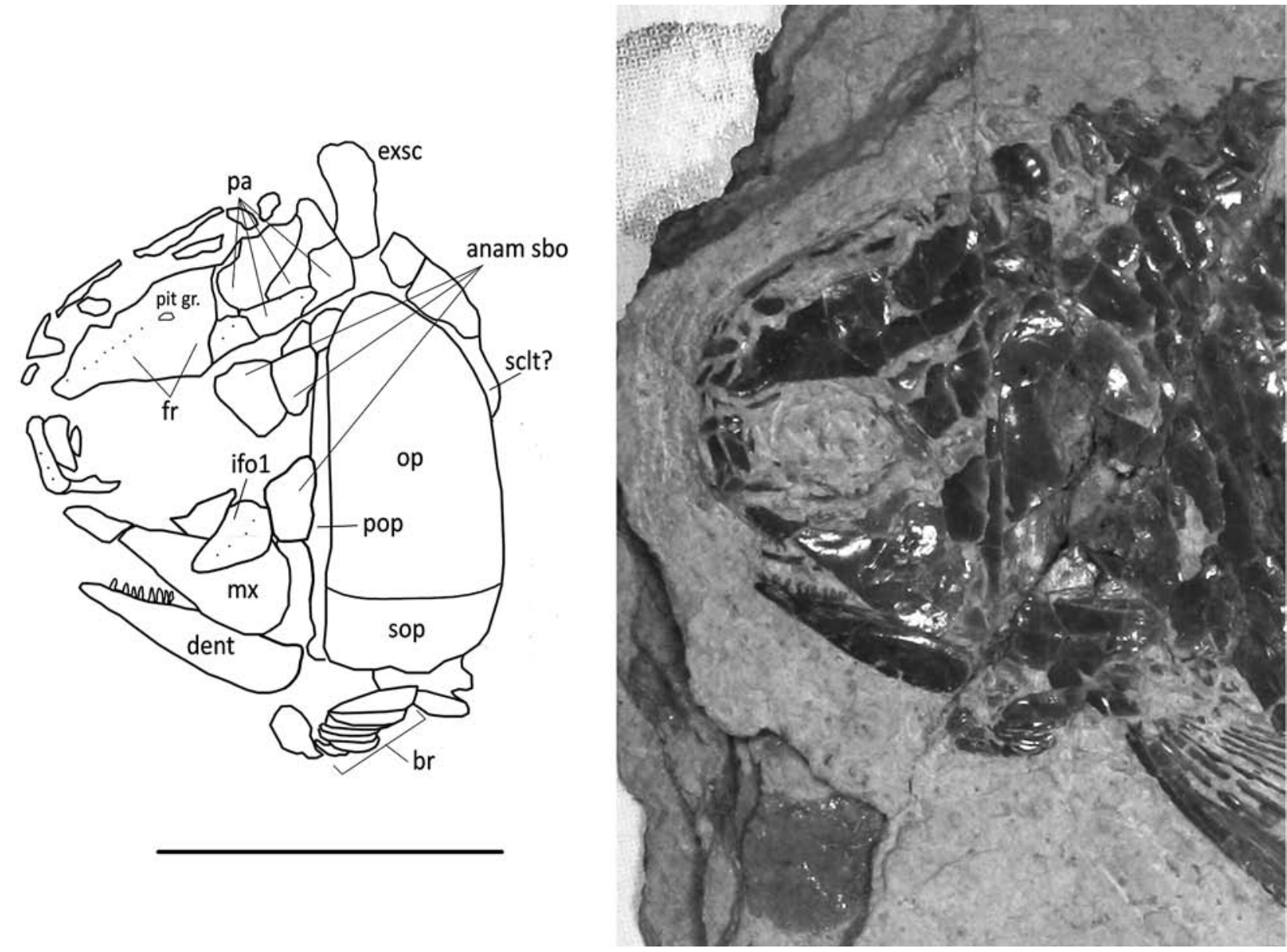

Fig. 6. Moradebrichthys vilasecae gen. et sp. nov. Skull (CERAM R007, paratype). Scale bar equals $1 \mathrm{~cm}$.

formed by the frontals, being almost rectangular and twice as long as wide and slightly larger posteriorly than anteriorly, which show a small depression dorsally. This area might have contained pit-organs. The lateral edges of the frontals are gently curved. In the anterior edge is not possible to see the indentation of the rostral bone but it can be observed lateral shallow indentation of the nasal bone.

The posterior part of the skull roof is formed by paired elements, the parietals and the dermopterotics, the latter placed behind the frontals (Fig. 5). These elements are almost squarish bones approximately $1 / 3$ shorter than the frontals and with irregular margins. The external surface of these bones is weakly ornamented by small punctuations (Fig. 9), but usually barely visible due to its state of preservation. At the posterior corners of the skull-roof there is a pair of rectangular extrascapulars only visible in one specimen (CERAM R007) (Fig. 6). The supraorbital sensory canal, marked dorso-laterally by series of tiny pores, is clearly visible in some specimens. Its course through the nasals and frontals is slightly $\mathrm{S}$-shaped and it merges posteriorly with a depression (or pit-grooves) on the frontal.
The constituing elements of the snout are only partially preserved in a few specimens but it is possible to see that is almost rounded and that it is built up of a median rostral (Fig. 9) and two lateral nasals (Fig. 5). The rostral is sub-rectangular, and the nasals are elongated and medially marked by a small notch for the anterior nostril (Fig. 5). The supraorbital sensory canal of the skull roof visible in some specimens (CERAM R002b, CERAM R007, IPS-89145 and IPS-89202) (Figs. 5-8) extends longitudinally connecting the rostral edge of the frontals with the pit-grooves.

Circumorbital series. The well-developed circumorbital series are made at least of two elongate supraorbitals and a triangular dermosphenotic bone forming respectively the dorsal and the postero-dorsal border of the orbit (Figs. 5, 8). The triangular dermosphenotic bone is in contact with the posterior infraorbital. The ventral and ventro-lateral borders of the orbit zone are composed of two big elements, the infraorbitals. The posterior one, forming the posteroventral margin of the orbit, is the infraorbital- 1 bone. Its morphology ressembles a half moon and is in contact with 


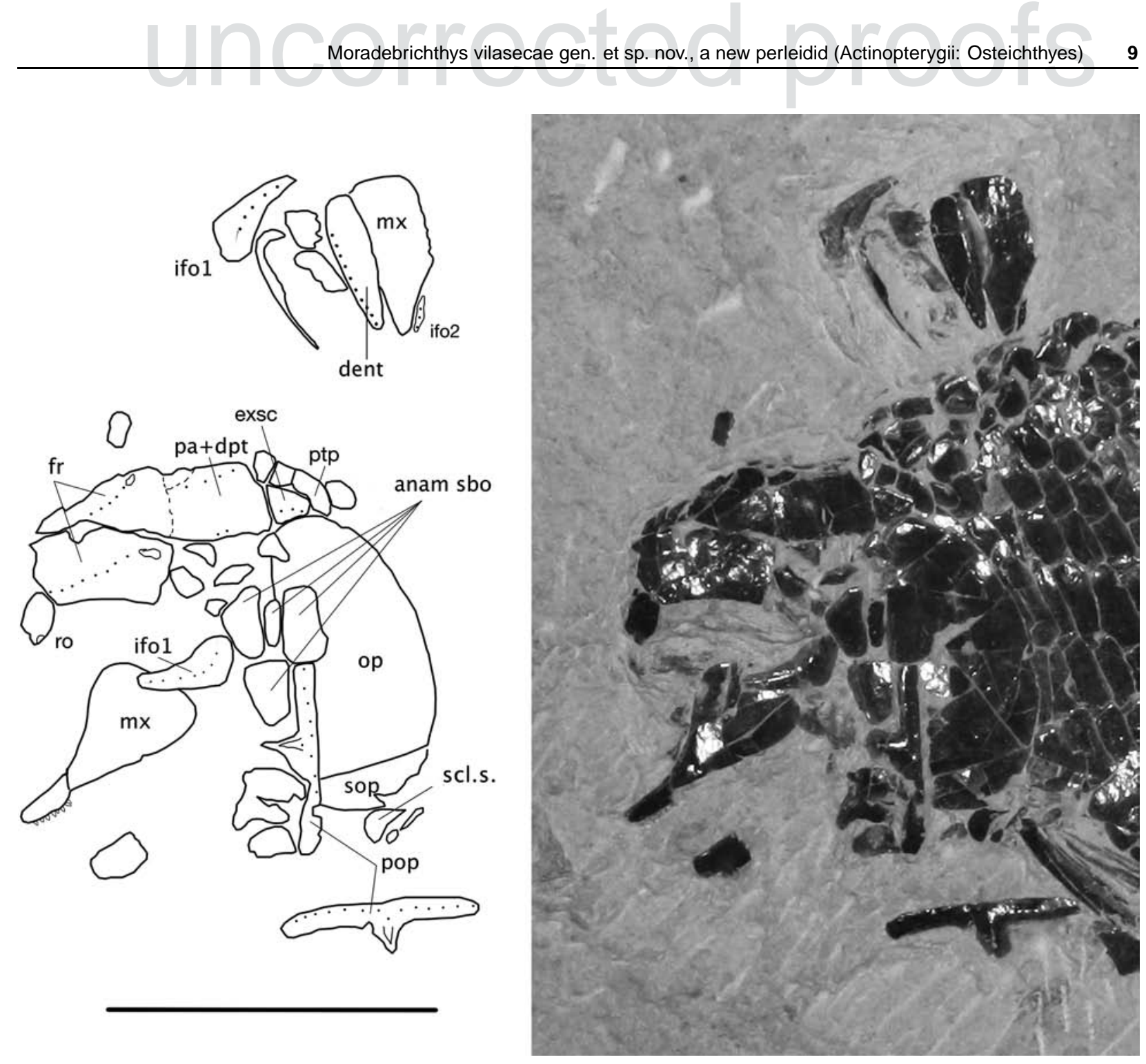

Fig. 7. Moradebrichthys vilasecae gen. et sp. nov. Skull (CERAM R002b, paratype). Scale bar equals $1 \mathrm{~cm}$.

the dermosphenotic, as it is possible to observe in specimen IPS-89202 (Fig. 8). This element, an elongate infraorbital-2 (Fig. 5), is bigger than the anterior one, that contacts in its anterior vertex with the maxilla. These infraorbital elements show in some specimens (i.e. IPS-89145; Fig. 5) series of small pores revealing the course of the infraorbital sensory canal.

Cheek-region. The cheek-region is characteristically formed by a vertical preopercle and a mosaic of small, anamestic suborbital bones of various shapes and sizes. The preopercle consists of a narrow shaft, with a prominent and pointed maxillary process anteriorly. Posteriorly the preopercle is grooved by the preopercular sensory canal. However, in some specimens a small horizontal pit-line at the base of the maxillary process (Fig. 7) is visible. A mosaic of anamestic suborbitals fills the space between the skull- roof, the infraorbitals and the rostro-dorsal half of the preopercle. The number and shape of the individual elements highly varies in the different specimens, but this morphological variation probably represents a preservational artifact; as example, there are four elements in CERAM R002b (Fig. 7), five in IPS-89145 (Fig. 5), three in CERAM R007 (Fig. 6), four in CERAM R010 or three in CERAM R004. In consequence, it is not posible to discern with confidence the real number of elements present due to preservational reasons.

Upper jaw. The upper jaw mainly consists of a large and robust maxilla. The maxilla consists of an anterior dentigerous plate and a deep posterior plate with a rounded dorsal margin and an almost right-angled postero-ventral corner (Fig. 5; IPS-89145). The ventral zone of the dentigerous anterior part of maxilla bears a densely set series of small 

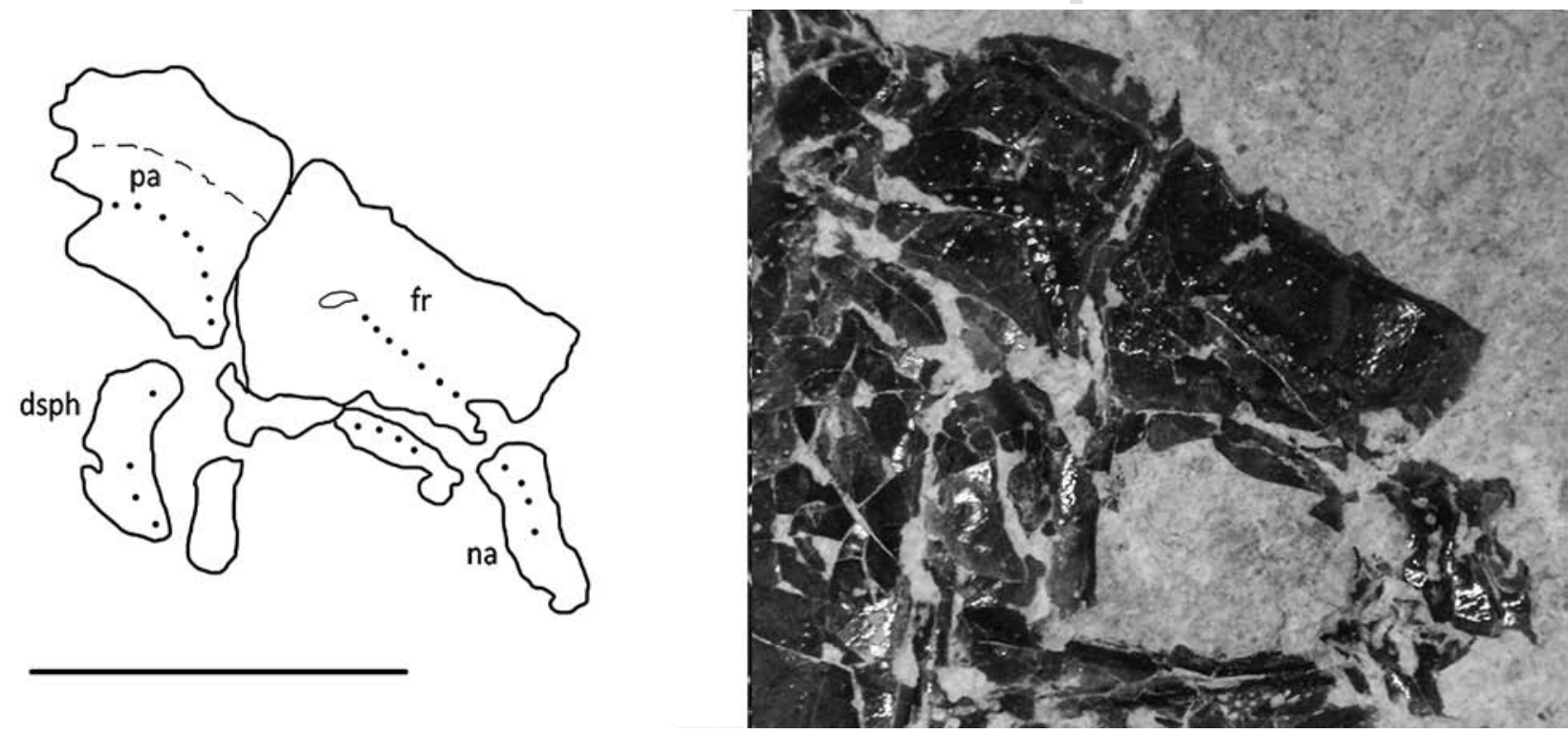

Fig. 8. Moradebrichthys vilasecae gen. et sp. nov. Cranial roof (IPS89202, paratype). Scale bar equals $0.5 \mathrm{~cm}$.

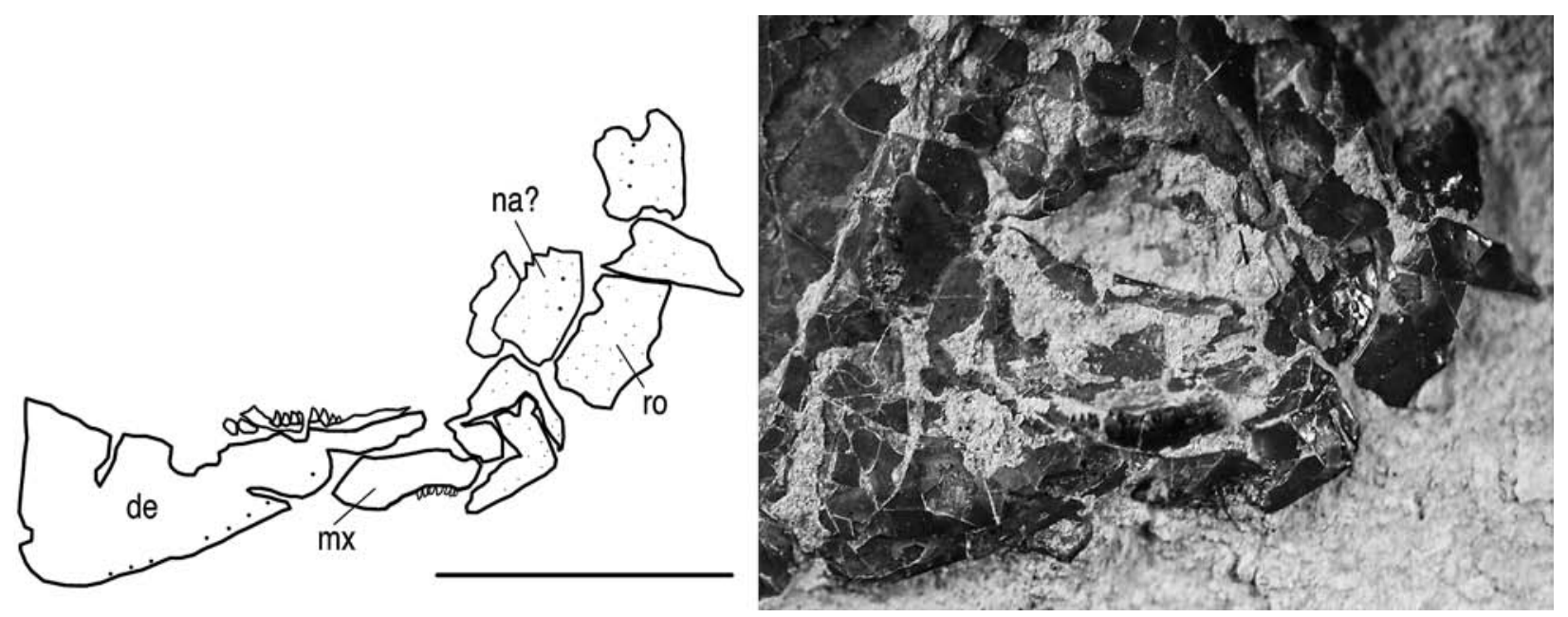

Fig. 9. Moradebrichthys vilasecae gen. et sp. nov. Detail of the dentary, maxilla, rostral and a potential nasal (IPS109801, paratype). Scale bar equals $0.5 \mathrm{~cm}$.

and pointed, conical teeth, which are slightly backwardly inclined (Fig. 9; IPS-109801). The posterior border is in total contact with the anterior border of the preopercle, while the dorsal border limits with the inferior borders of the infraorbital bones. The premaxilla is not clearly identifiable on any specimen.

Lower jaw. The lower jaw is wedge-shaped and is not possible to see a coronoid process in the dentary. The dentigerous margin bears a low number of closely set, peg-like and pointed teeth, only partially visible in six specimens (CERAM R002, CERAM R004, CERAM R007, CERAM R010, IPS-89202 and IPS-109801) (Figs. 5-7, 9). Due to the state of preservation it is not possible to evaluate the presence of a separate angular in any specimen. The dentary is covered by some horizontally arranged ridges (Fig. 10), and a longitudinal series of small pores that indicates the inferior course of the sensory canal, as can be observed in CERAM R001, CERAM R002b, CERAM R004, CERAM R007, CERAM R010, CERAM R030, IPS-89145, IPS-89166, IPS-89202 and IPS-109801.

Opercular and branchiostegal series. The gill-cover is composed of a large shield-like opercle and a very much smaller subopercle. The opercle has a gently rounded posterior margin and a straight, almost horizontal ventral edge. 

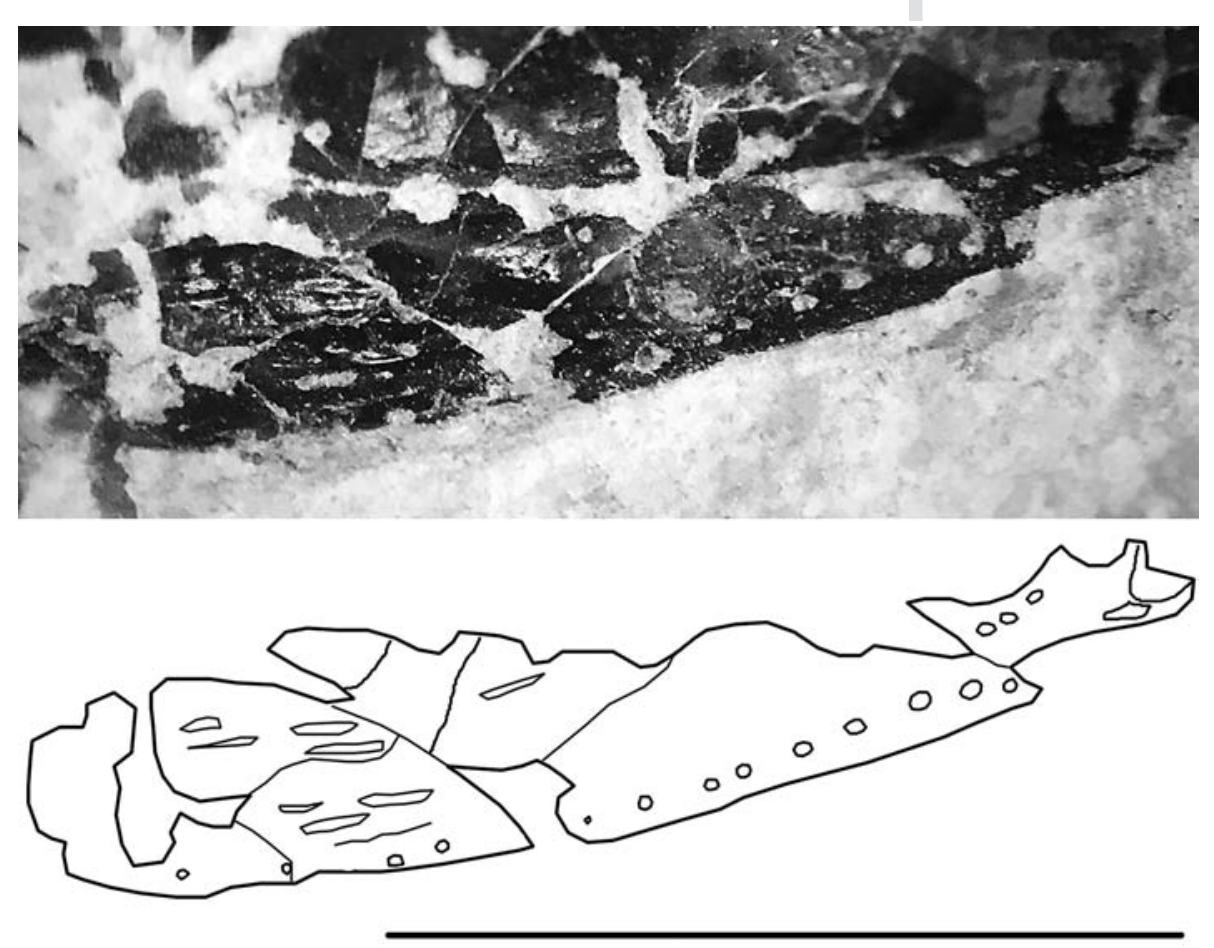

Fig. 10. Moradebrichthys vilasecae gen. et sp. nov. Detail of the dentary ornamentation (IPS89202, paratype). Scale bar equals $0.5 \mathrm{~cm}$.

The subopercle has a posteroventral rounded border. The gular series are not visible. The branchiostegal series are usually not preserved except in CERAM R007 and in IPS-109792, where they present 7 elongated and flattened branchiostegal rays without any trace of ornamentation (Figs. 6, 11).

Pectoral girdle and fins. The pectoral girdle consists of a subrectangular postemporal, a deep and thin supracleithrum and a sickle-shaped cleithrum, well exposed in IPS-89145 and CERAM R002b (Figs. 5, 7). It is possible to observe in just one specimen, IPS-89145, practically all whole portions of the postemporal and the extrascapular of one side (Fig. 5), of medium size and subtriangular shape, separated from each other by a couple of scales. It is not possible to discern the sensory canal in the postemporal bone, which connects the lateral line of the body with the cephalic branches of the sensory canals. The supracleithrum is elongated with a more rounded dorsal and a pointed ventral end. It surrounds the posterodorsal border of the opercular and its margin is very close to upper part of the cleithrum, approximatelly at the level of the middle posterior border of the opercular. Its anterior margin is hidden by the opercular in all the specimens. The anterior margin of the cleithrum is also hidden by the opercular and the subopercular. The dorsal tip of the cleithrum is vertically oriented, elongate and pointed, whereas the posterior part is deeply indented for the pectoral fin insertion. There is a postcleithral scale in CERAM R002b (Fig. 7).
The pectoral fin is moderately large (Fig. 3A). It is composed of about 9-13 lepidotrichia, which are only distally segmented (Fig. 12A, B). The first ray is rather spinous. It is not possible to assess if the lepidotrichia are distally branched. A series of small fringing fulcra are visible in the leading edge. In the first rays it is possible to observe an articulation facet (Fig. 12A).

Pelvic fins. Due to preservational reasons the pelvic girdle is not visible. The pelvic fins are smaller than the pectorals and each one is located after the maximum body depth, between scale rows 8-10. They are composed of about 6-7 lepidotrichia, at least distally segmented. The leading edge of each fin is preceded by three or four basal fulcra, but no trace of fringing fulcra is visible along the leading fin lepidotrichia (Fig. 12C).

Dorsal fin. The dorsal fin is triangular and located between scale rows $20-26$, inserted posteriorly to the maximum depth of the body. Two basal fulcra are followed by lepidotrichia (Fig. 13A). At least 12 distally segmented lepidotrichia form the fin. The leading one bears at least three fringing fulcra (Fig. 13A). In two specimens (CERAM R007, CERAM R020) it is possible to observe four anterior and almost contiguous lepidotrichium, whereas the posterior ones are more spaced (Fig. 13A, B). It is not posible to assess if the lepidotrichia are branched. 

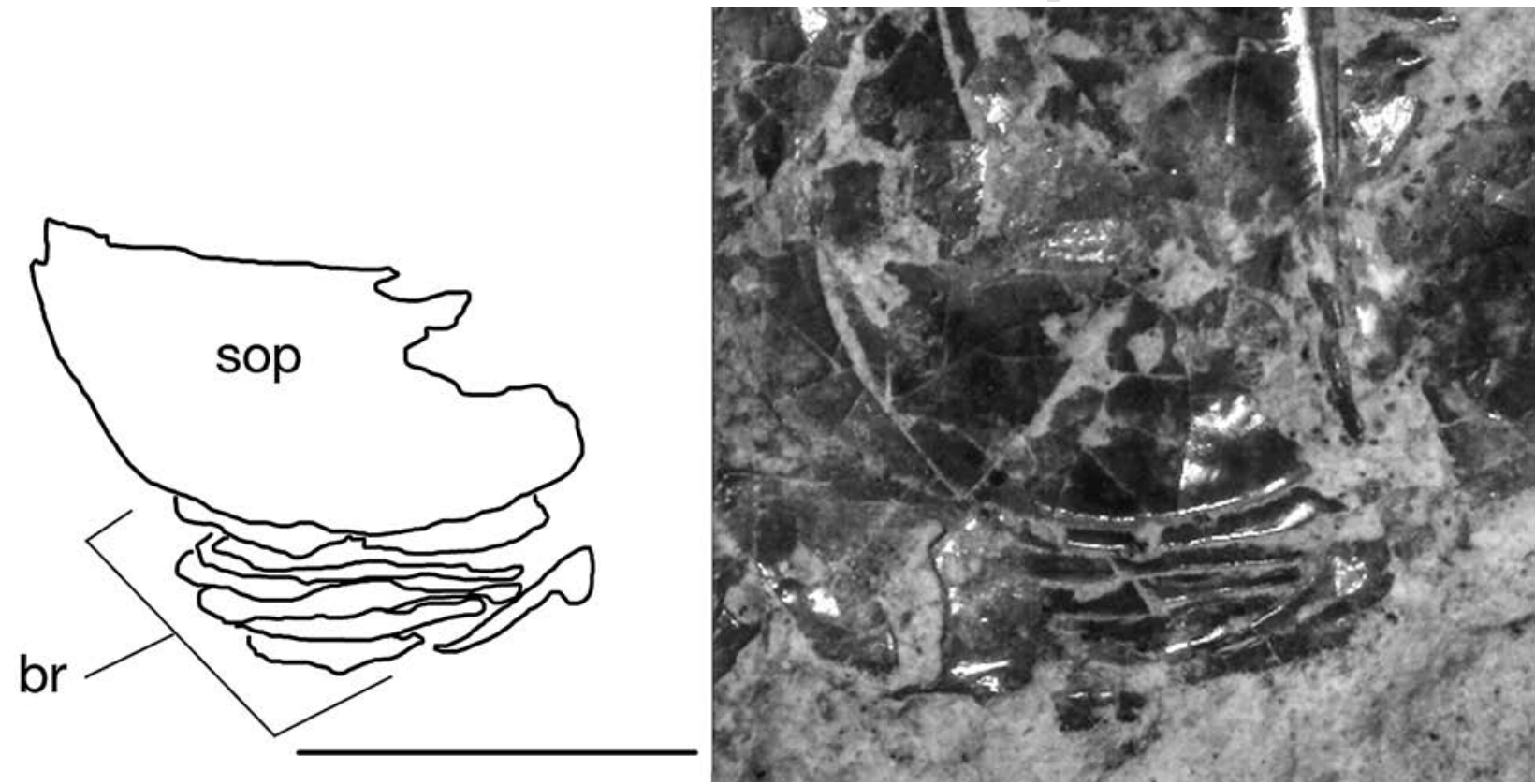

Fig. 11. Moradebrichthys vilasecae gen. et sp. nov. Branchiostegal rays detail (IPS109792, paratype). Scale bar equals $0.5 \mathrm{~cm}$.

Anal fin. The anal fin is inserted between scale rows 18-21 and is almost as large as the pectoral fins. It is also triangular and is composed of $8-10$ distally segmented lepidotrichia similar in structure to those of the dorsal fin, with three basal fulcra (Fig. 13D). It is not possible to see the fringing fulcra along the leading fin lepidotrichia in any specimen, due to preservational reasons.

Caudal fin. The caudal fin is almost symmetrical, rathed deeply forked, with a very short axial body lobe, and a total of 30-36 lepidotrichia. There are about 2-3 basal fulcra and 6-7 epaxial procurrent lepidotrichia in the dorsal lobe, whereas in the ventral lobe there are 1-2 basal fulcra. The most common number of rays (Fig. 13) is 24-30. The ventral leading lepidotrichia bears a series of small fringing fulcra (CERAM R001; Fig. 13C). The 8-10 central lepidotrichia are branched at least twice, whereas the other ones, from each side (dorsally and ventrally), are branched only once, except the first leading one (Fig. 13D).

Endoskeletal elements. The bases of the unpaired median fins are usually covered by scales except in the dorsal fin of one specimen (CERAM R007; Fig. 13A); in this case some of the endoskeletal elements can be observed. The distal rays visibles are only 6, as is possible to see in Fig. 13A: they are large and rectangular with weakly thickened margins; each radial joins one lepidotrichium, but it is not possible to see the ones starting and ending in the dorsal fin, for this reason is impossible to see if exist one or more radials that support more than one lepidotrichium.
Scales. There are up to 41 vertical scale rows counted along the lateral line. There are about five horizontal scale rows above the row containing the lateral line canal and 7-9 below. The scales from the anterior region of the trunk are deeper than wide. They become gradually smaller towards the caudal region. The axial lobe is very small and inconspicuous (Fig. 14A). The scales from the anterior flank region are rectangular (Fig. 14B). The depth of rectangular scales decreases posteriorly towards the caudal region where they become rhomboidal (Fig. 14C). The lateral line runs through the dorsal part of the two most deepened flank scales and turns towards the middle in the more posterior scales.

\section{Discussion}

'Perleidiformes' is a group of actinopterygians known from marine and continental Triassic sediments (BERG 1937; SCHAEFFER 1955; GARDINER 1967; HutCHINSON 1973; MUtTER 2002; LOMBARDO et al. 2008; López-Arbarello \& Zavattieri 2008). During the last 25 years the monophyly of the group has been questioned. GARDINER \& SchaEFFER (1989) conducted the first cladistic analysis of different actinopterygian groups naming 'Perleidiformes' as the 'Perleidus group', concluding that the group was probably not monophyletic. Later, MutTer (2002) conducted a new cladistic analysis focused on the Colo- 


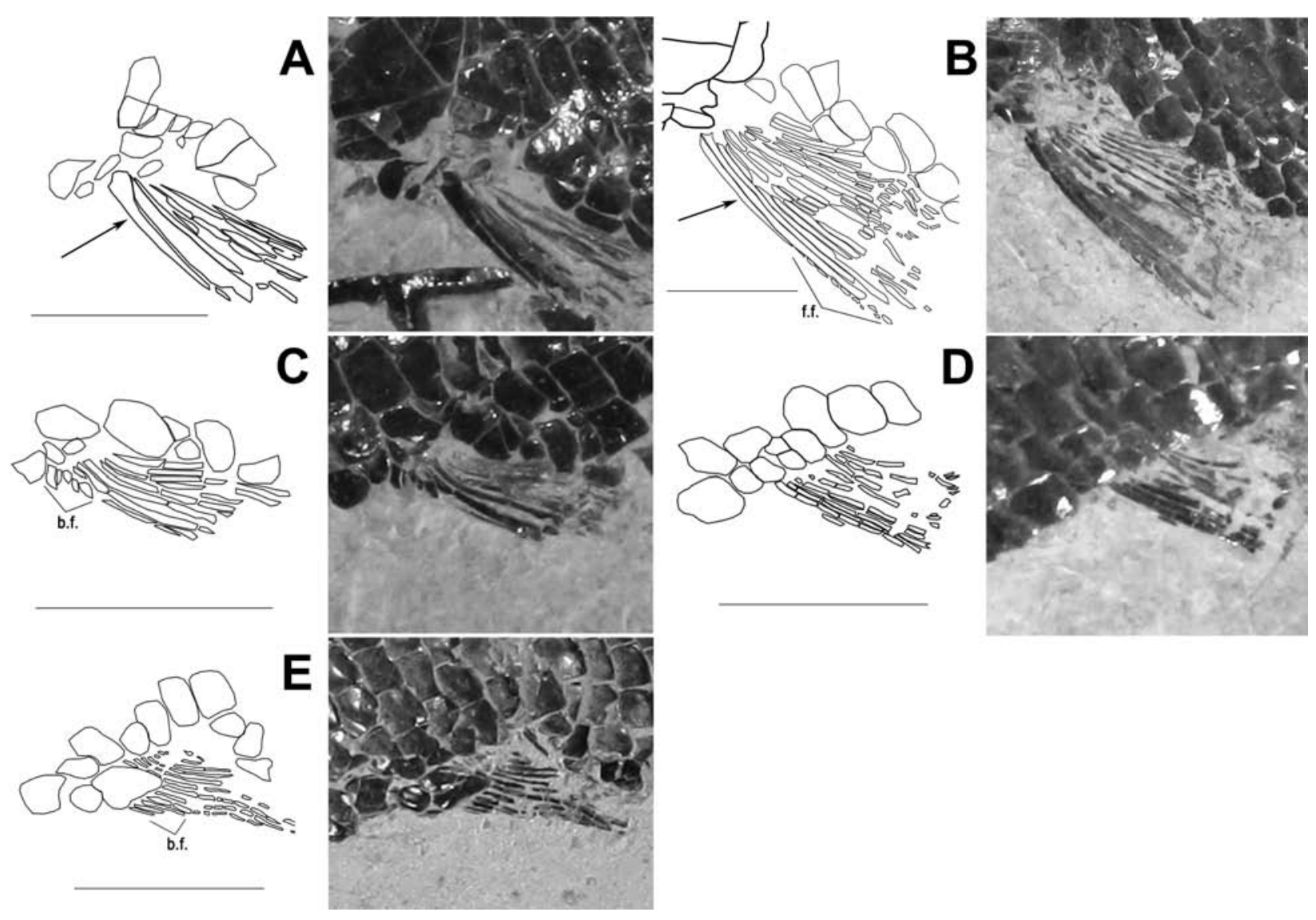

Fig. 12. Moradebrichthys vilasecae gen. et sp. nov. Paired fins. A, pectoral fin (CERAM R002b, paratype); B, pectoral fin (CERAM R007, paratype); C, pelvic fin (CERAM R002b, paratype); D, anal fin (CERAM R007, paratype); E, anal fin (CERAM R020, paratype). Scale bar equals $0.5 \mathrm{~cm}$.
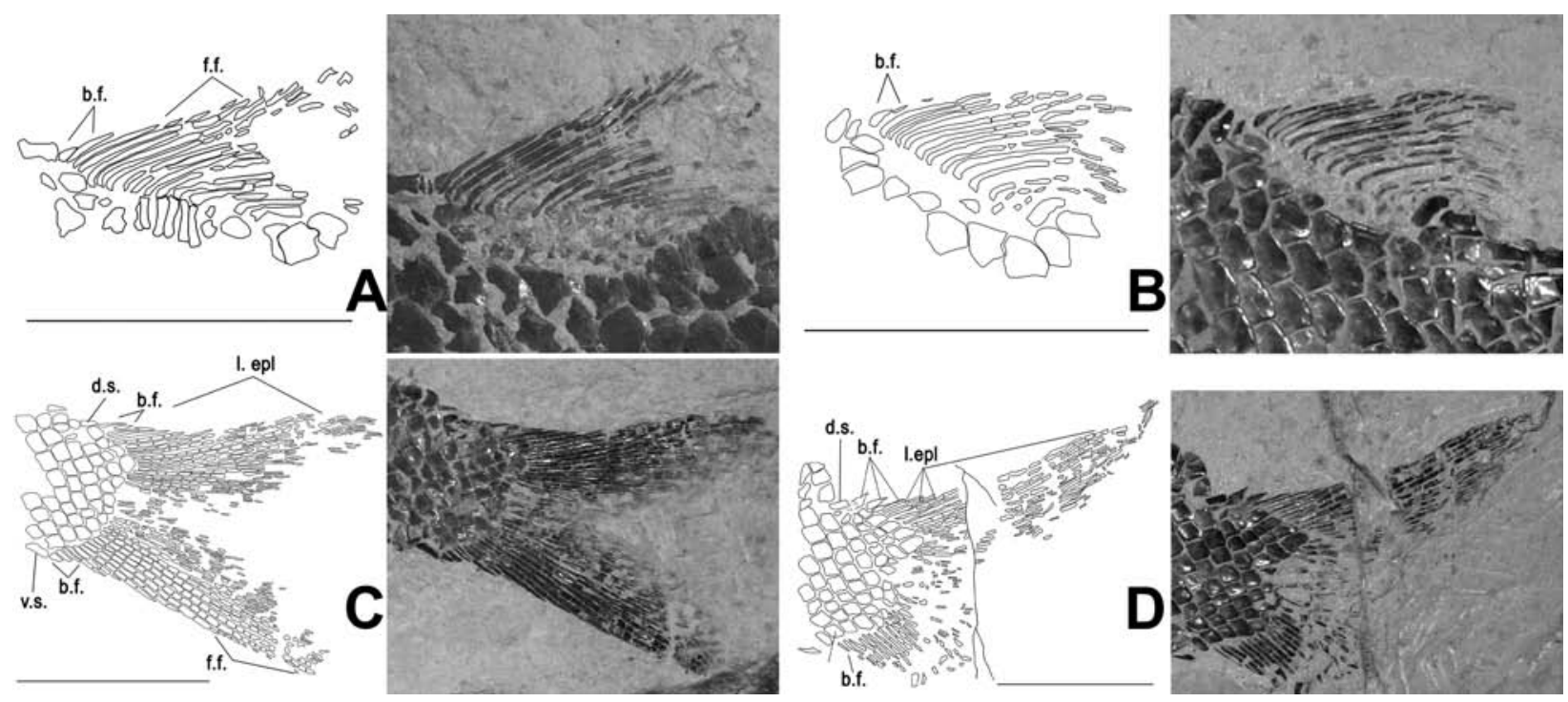

Fig. 13. Moradebrichthys vilasecae gen. et sp. nov. Unpaired fins. A, dorsal fin (CERAM R007), ; B, dorsal fin (CERAM R020, paratype); C, Caudal fin (CERAM R001, holotype); D, Caudal fin (CERAM R020, paratype). Scale bar equals $1 \mathrm{~cm}$. 


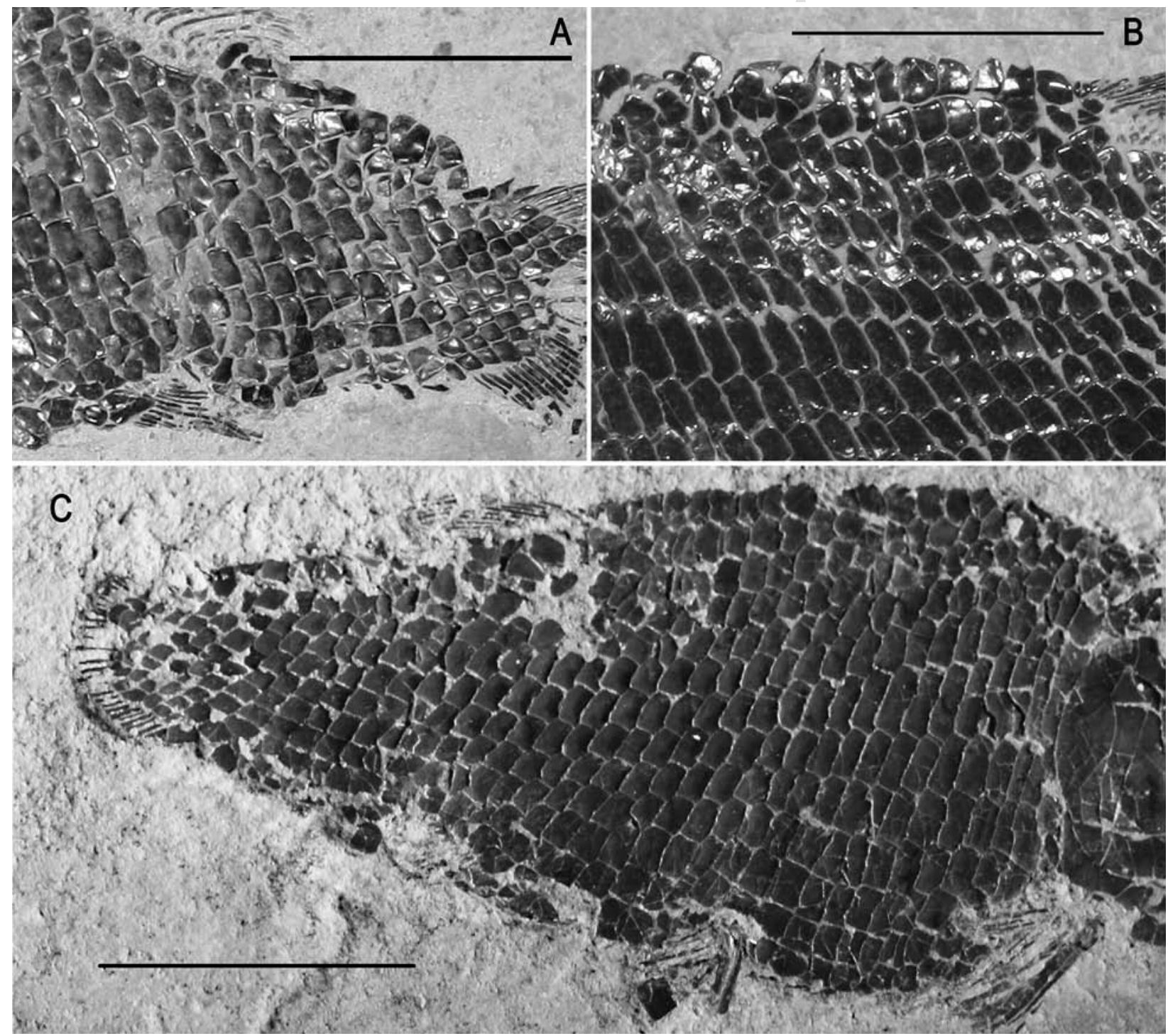

Fig. 14. Moradebrichthys vilasecae gen. et sp. nov. A, Squamation in the posterior part of the body (CERAM R020, paratype); B, Squamation in the central region of the body (CERAM R002b, paratype); C, Squamation of total body (IPS89145, paratype).

bodontidae family, but including all the perleidiform genera, and concluded also that this group is not monophyletic. Moreover, he considered that two characters, durophagous teeth and maxilla's posteriordorsally expanded plate should be not considered as diagnostic characters. In 2008, LóPEZ-ARBARELLO \& ZAVATTIERI considered that no previous works confirms the monophyly of 'Perleidiformes', but concluded that at least several perleidiform taxa share a combination of characters unique among primitive actinopterygians (López-Arbarello \& Zavattieri 2008). More re- cently, Sun etal. (2012) performed a new cladistic analysis of many well-known perleidiforms and their results suggested that the perleidiform clade is monophyletic, but with low bootstrap support value, and that future analyses should deep into this issue. Finally, XU et al. (2015) performed a new cladistic analysis concluding that 'Perleidiformes', but also 'Peltopleuriformes', are paraphyletic, encompassing several independent stem-neopterygian subclades. It is out of the scope of the present article to explore the potential monophyly of the 'Perleidiformes', but these con- 
siderations should be taken into account to discuss the allocation of new taxon herein reported.

We explored the systematic position of the taxon studied herein using the framework provided by López-Arbarello \& ZaVATtieri (2008) and SUN et al. (2012, 2013), and compared Moradebrichthys vilasecae gen. et sp. nov. with the taxa included in those studies. We revised the scorings in both matrices as well as the figures of the original papers of the genera Dipteronotus (TinTORI 1990) and Manlietta (WADE 1935; Hutchinson 1973). Moreover, one of us examined on first hand (J.C.) the holotypes of the genera Peltoperleidus (BÜRGIN 1992) and Ctenognathichthys (BÜRGIN 1992; TINTORI 1998) stored at the Paläontologisches Institut und Museum der Universität Zürich, Switzerland (PIMUZ). Based on these considerations we have been able to confirm some of the changes made by Sun et al. (2012), but not all.

After one of us accessed (J.C.) first hand the holotype (PIMUZ A/I 1174) and other specimens (PIMUZ A/I 1124 and PIMUZ A/I 1174) ofPeltoperleidus, the scoring of character \#26 - posterior border of scales (serrated/smooth) by Sun et al. (2012) is well justified.

Regarding the genus Manlietta, LóPEZ-ARBARELLO \& ZAVATTIERI (2008) and SUN et al. (2012) indicated in their respective papers that the scoring was only based on the original articles without studying the original material first hand. Based also only on the original papers, checking photographs, drawings and descriptions provided by the authors (WADE 1935: figs. 29, 30, pl. 9, fig 1; Hutchinson 1973: figs. 36, 37 ), we agree with the changes suggested by Sun et al. (2012), but we recommend a revision of the original material to avoid ambiguous interpretations.

Regarding Ctenognatichthys, after one of us (J.C.) first-hand studied the holotype, we agree with the scoring of López Arbarello \& ZAVATtieri (2008), and differ from the opinion of SUN et al. (2012) regarding character \#2 - Quadratomandibular articular, being at about the posterior border of the orbit, not well anterior to the posterior border of the orbit. Finally, in the case of Dipteronotus, we agree with most of the changes proposed by Sun et al. (2012), except in the case of the character 26, where we support the view of López Arbarello \& ZaVATtieri (2008) that regarded the state as unknown. We discuss below each character change proposed by Sun et al. (2012); we agree with: \#2 - quadratomandibular articulation far behind the posterior border of the orbit, not at about the posterior border of the orbit as proposed by LóPEZ ARbARELlo \& ZaVATTIERI (2008). Otherwise, charac- ters \#6 and \#9 were scorded as missing data by LóPEZ ARbARELlo \& ZAVATTIERI (2008), but regarding \#6 we agree with Sun et al. (2012) that nasal bones reach antorbitals ventrally, whereas in \#9 suborbital bones are present, as firstly showed by SUN etal. (2012). Regarding \#13, we agree with Sun etal. (2012) that crushing dentition is absent in this taxon and that preopercle is well enough preserved to consider that is narrower ventrally than dorsally and that infraorbital process of preopercle is present. Regarding \#17, flank scales, the shape of them is two or three times deeper than long, in agreement with Sun et al. (2012). Lastly, regarding character \#18, we consider that dorsal and anal fins placed very close to the caudal fin should be considered as absent.

\section{Taxonomic remarks}

The general morphology of Moradebrichtys vilasecae gen. et sp. nov. agrees with the characters given by BERG (1937) as diagnostic for 'Perleidiformes': body outline deeply fusiform, width of gape variable, commonly moderate; snout with a large rostral dividing the nasals; maxilla well-expanded posteriorly, where it contacts the anterior edge of a vertically oriented preopercular; large opercular region; almost symmetrical caudal fin with epaxial rays, unevenly segmented and long based fin rays; scaly lobe always very short; scales deeper than broad on the anterior region of the body. Therefore, the new taxon is referred to this group (but see above for the possible paraphyly of the group).

Within the 'Perleidiformes', eight families are currently recognized based on the published studies by different researchers to date (BROUGH 1931; BROUGH 1939; De Alessandri 1910; Hutchinson 1973; GARDINER 1988; BÜRGIN 1992; TINTORI \& LOMBARdo 1996; MutTer 2004; LóPEZ-ARbaRELlo \& Zavattieri 2008; Sun etal. 2013): Cleithrolepididae, Polzbergiidae, Colobodontidae, Gabanellidae, Luganoiidae, Pseudobeaconidae, Fuyuanperleididae, and Perleididae.

Cleithrolepidae and Polzbergidae are deep-bodied and laterally flattened forms, very different from Moradebrichthys. Other differences between Cleithrolepidae and the new taxon are a different size relation between opercle and subopercle (in Moradebrichthys the opercle is deeper than the subopercle) and the surface ornamentation of scales (in Cleithrolepidae they are ornamented with fine tubercles). Polzbergidae have further differences such as a subop- 
ercle fused with ventral part of subdivided preopercle and a powerful well-developed premaxilla.

Moradebrichtys vilasecae gen. et sp. nov. differs from Colobontidae in that members of this group are large sized 'perleidiforms' with strong ornamentation of ganoine in the dermal bones of skull, and longitudinal ridges of ganoine in the free surface of scales.

Gabanellidae are large 'perleidiforms' with thin scales arranged in about 95 rows and with a powerful dentition, characters not shared with the new taxon. The opercular and check regions of Luganoidae are different from Moradebrichthys. In the latter, the subopercle is smaller than the ones found in Luganoidae. The morphology of the snout is also very different: the tip of the snout of the members of Luganoidae is much more pointed than it is in Moradebrichthys. Regarding Pseudobeaconidae, the squamation pattern in this group includes flank scales approximatelly three times deeper than long and spinous mid dorsal scales. None of these features are present in the specimens of Moradebrichthys. Moradebrichthys differs from Fuyuanperleididae in size, but also in that it does not share with them the peculiar squamation pattern: the number of scales in each vertical row increases behind the pelvic fins.

Of particular interest, the new taxon herein described shares several characters with the family Perleididae. However, there is no consensus about the alpha taxonomy of perleidids and the diagnostic features that characterize them. Nonetheless, Moradebrichtys shares most of the characters usually considered to define its members, as for example: snout with nasals separated by rostral; paired premaxillae and rostral present; maxilla with concave dorsal border, expanded posteriorly, nasals forming the anterior margin of the orbit; suspensorium nearly vertical; branchiostegals present; mandible without coronoid process; basal and fringing fulcra on fins variously developed; fin rays segmented in distal portion only, except in caudal where rays are completelly segmented; caudal fin scarcely to moderately forked, hemiheterocercal; scales and dermal bones smooth. However, the different phylogenetic analyses published to date (Lopez-Arbarello \& Zavattieri 2008; Sun et al. 2013; XU et al. 2015 and references therein) do not provide support regarding the perleidid affinities of most of the genera referred to this family (see below).

To date, up to nine genera are usually considered members of this family: Perleidus, Meridensia, Aetheodontus, Peltoperleidus, Dipteronotus, Ctenognathichthys, Daninia, Endennia, and Chaohuperlei- dus (Sun etal. 2013). Recently, Sun etal. (2015) moved the genus Altisolepis, a former member of the Perleididae, to the Peltopleuridae.

The new taxon here described cannot be assigned to any previously erected genus due to the combination of characters present and differences with the rest of the supposed perleidid taxa.

Dipteronotus is highly different in its general bodysize: it is a high-bodied taxon with a long dorsal crest, not present in Moradebrichthys. Ctenognatichthys, Daninia and Endennia have a strongly developed oral dentition consisting of more powerful teeth than those of Moradebrichthys. These three taxa also have a subopercle bigger than the opercle, while in the new taxon the opercle is notably bigger than the subopercle. Chaohuperleidus shows scales that are denticulated on the posterior margin and the anterior ones showing faint longitudinal ridges, whereas Moradebrichthys show scales are without ridges or denticulated margin. The new taxon has 67 epaxial rays in the caudal fin, approximately four more than Chaohuperleidus. Compared with Perleidus and Peltoperleidus, the new taxon lacks the wide dorsal region in the preopercle and its subopercle is signifficantly smaller. Perleidus is different in the squamation pattern based on serrated scales posteriorly and Peltoperleidus in the two high deepened rows of flack scales that persist back to the level of anal fin insertion, but at least it shares with both (Perleidus and Peltoperlei$d u s$ ) the size and the external shape of the body and the number of epaxial rays (6-7). Regarding Aetheodontus and Meridensia, these two genera present certain morphological similarities with the taxon recovered in Móra d'Ebre - Camposines outcrops. The three taxa share the external shape and the size of the body, the equilobate caudal fin, the vertical oriented preopercle, and the size and shape of the paired fins. In comparison with Meridensia, differences are observed in the caudal fin: in Moradebrichthys there is not a clearly pronounced forked form as present in Meridensia (HutchINSON, 1973). In comparison with Aetheodontus, this latter genus presents a squamation of about 17-20 scales in the vertical row at the maximum depth of the trunk and about 45-50 scales along lateral line, whereas the squamation in the taxon described herein is composed along the lateral line of about 36-40 vertical scale rows and 12-14 in vertical row at the maximum depth of the body, similar to the one present in Meridensia. Moreover, additional morphological characters are present in the Catalan taxon not shared with any of the two previously discussed 
genera: one big half moon shaped infraorbital-2 and one elongate infraorbital-1, narrow vertical preopercle with a prominent and pointed anterior maxillary process, a very big opercle and a much smaller subopercle, and the high level of lepidotrichia branching in the caudal fin.

\section{Palaeonvironmental observations}

The members of the Perleididae family are known from the Anisian (Middle Triassic) to the Norian (Late Triassic). At the nearby and rich classical Alcover outcrops, known perleidids are Perleidus, Peltoperleidus and Ctenognathichthys (Beltan 1972; Beltan 1975; Beltan 1984; CARTANYÀ 1999). However, similar forms to the new taxon herein reported are unknown there. The Alcover outcrops represent the development of extensive shallow water over the region after the progressive filling of the inter-reef depressions, whereas the Rasquera Unit (where the material herein reported was recovered) is interpreted as a proximal deep ramp (CALvet etal. 1990). Moreover, this interpretation could be reinforced by the increased presence of ammonoids (Protrachyceras hispanicum and Hungarites sp.). Usually the deposits in the alpine zone (Italian and Swiss outcrops, e.g., Meride, Monte San Giorgio, Besano) are deeper platforms than the Alcover outcrops, and maybe Móra d'Ebre-Camposines outcrops could share more ecological similitudes with those Central European areas due to this platform features rather than to the Alcover area. However, further studies are required to assess this question.

\section{Conclusions}

Several actinopterygian specimens were collected at Móra d'Ebre-Camposines site. Most of them are referred to a new taxon, Moradebrichthys vilasecae gen. et sp. nov.

These new findings, recovered in the upper levels of the Calcàries i/o dolomies de Rasquera Unit (Catalan Basin, Catalonia, Spain), dated as Late Ladinian, show sufficient preservation to provide a new window for the study of the Iberian Triassic actinopterygian fauna. The new material found in the Móra d'EbreCamposines levels will allow to increase our knowledge of the marine Triassic ecosystems, and specially about the actinopterygian group of 'Perleidiformes' that represent the greatest part of the actinopterygian diversity in the site.

The new genus herein reported is described based on several specimens. Moradebrichthys vilasecae gen. et sp. nov. is interpreted as a 'perleidiform' on the basis of several characters: body outline deeply fusiform, width of gape variable, commonly moderate; snout with a large rostral dividing the nasals; maxilla well expanded posteriorly where it contacts the anterior edge of a vertically oriented preopercular; large opercular region; almost symmetrical caudal fin with epaxial rays, unevently segmented and long based fin rays; scaly lobe always very short; scales deeper than broad on the anterior region of the body. Comparison with the different perleidiform families reveals that the Móra d'Ebre-Camposines taxon ressembles Perleididae and represents a new taxon based on its unique combination of characters. Moradebrichthys vilasecae gen. et sp. nov. is closely related to the genera Perleidus and Peltoperleidus, but in comparison to these two genera it lacks the wide dorsal region in the propercle and its subopercle is significantly smaller. It seems to also be closely related with Meridensia, but differs from it in several characters.

The combination of characters only found in Moradebrichthys vilasecae gen. et sp. nov. are: one elongate infraorbital-1 and one big infraorbital-2, a narrow vertical preopercle with a prominent and pointed anterior maxillary process, a very big opercle and a much smaller subopercle, and the high level of lepidotrichia branching in the caudal fin. This combination of characters allow the erection of a new taxon.

The Móra d'Ebre-Camposines outcrops present a lower taxonomical diversity than the nearby classical Alcover outcrops (Mirabal 1998; CARTANYÀ 1999). Comparison of assemblages from the latter with other Middle Triassic actinopterygian faunas, coming from Italian and Swiss localities in Alpine facies, shows some similarities. The closest similarity might be with the Besano Formation (BÜRGIN 1992; CARTANYÀ 1999), as Perleidus, Meridensia and Aetheodonusare known from both outcrops. However, Alcover outcrops also share other genera such as Peltoperleidus, Saurichthys or Ctenognathichthys with Prosanto and Perledo localities (Swiss and Italy, respectively).

Future discoveries of fossil actinopterygian remains and in progress studies of additional specimens (some of them clearly different from Moradebrichthys) from Móra d'Ebre-Camposines are expected to provide additional data in order to ascertain possible relation- 
ships between the faunas of different basins of the Middle Triassic of Europe.

\section{Acknowledgements}

Our special thanks go to Rafel Mirabal. The field team members are acknowledged, particularly NovELLA Razzolini, Alba Vicente, Eudald Mujal, Meritxell Fernandez-Coll, Marta Garcia-Gamez, Ramon Mercedes-Martin and Marc Riccetto. Thanks also to the owners of the Móra d'Ebre-Camposines quarry, JAUME Llorens, Teresa Valls, and also to Miquel Roca of Móra d'Ebre for their kind collaboration. J.F. was supported by the postdoc grant "Beatriu de Pinós" 2014 BP-A 00048 from the Generalitat de Catalunya and by the Spanish Ministerio de Economía, Industria y Competitividad (MINECO), the European Regional Development Fund of the European Union (MINECO/AEI/FEDER EU, project CGL2017-82654-P. Fieldworks were performed under the projects "Vertebrats del Permià i el Triàsic de Catalunya i el seu context geologic", "Evolució dels ecosistemes amb faunes de vertebrats del Permià i el Triàsic de Catalunya" (ref. 2014/100606) and "Evolució dels ecosistemes durant la transició Paleozoic-Mesozoic a Catalunya" (ref. CLT009/18/00066), financially supported by the Departament de Cultura (Generalitat de Catalunya). This research paper is a contribution to the Cerca program (Generalitat de Catalunya). We acknowledge constructive suggestions and comments for improvements of the manuscript made by the editor and two anonymous reviewers. A.B. is also supported by a Newton International Fellowship (NF170464).

\section{References}

D'Archiac, A. (1860). Histoire des progrés de la géologie de 1834-1849. Paris: Societé Géologique de France.

Beltan, L. (1972). La faune ichthyologique du Muschelkalk de la Catalogne. Memorias de la Real Academia de Ciencias y Artes de Barcelona, 41(10), 281-325.

Beltan, L. (1975). A propos de l'ichthyofaune triasique de la Catalogne espagnole. Colloques internationaux C.N.R.S., 218, 273-280.

Beltan, L. (1984). Quelques poissons du Muschelkalk superieur d'Espagne. Acta Geologica Hispanica, 19(2), $117-127$.

BERG, L.S. (1937). A classification of fish-like vertebrates. Bulletin de l'Académie des Sciences de l'URSS, 1937, 1277-1280.

Brough, J. (1931). On the fossil fishes from the Karoo System, and some general considerations on the bony fishes of the Triassic period. Proceedings of the Zoological Society of London, 1931, 236-295.

Brough, J. (1939). The Triassic Fishes of Besano, Lombardy. 117 pp.; London: British Museum, Natural History.

BürgIN, T. (1992). Basal ray-finned fishes (Osteichthyes; Actinopterygii) from the Middle Triassic of Monte San Giorgio (Canton Tessin, Switzerland). Schweizerische Paläontologische Abhandlungen, 114, 1-164.
Calvet, F., \& Marzo, M. (1994). El Triásico de las Cordilleras Costero Catalanas: estratigrafía, sedimentología y análisis secuencial. In A. Arche (Ed.), Excursiones del III Coloquio Estratigráfico y Paleogeográfico del Pérmico y Triásico de España (pp. 1-53). Cuenca, Spain.

Calvet, F., \& Ramon, X. (1987). Estratigrafia, sedimentologia y diagénesis del Muschelkalk inferior de los Catalánides. Cuadernos de Geologia Ibérica, 11, 141-169.

Calvet, F., \& Tucker, M.E. (1988). Outer ramp cycles in the Upper Muschelkalk of the Catalan Basin, northeast Spain. Sedimentary Geology, 57(3-4), 185-198. doi: 10.1016/0037-0738(88)90026-7

Calvet, F., \& Tucker, M.E. (1995). Mud-mounds with reefal caps in the upper Muschelkalk (Triassic), eastern Spain. In C.L. V. Monty, D.W. J. Bosence, P.H. Bridges, \& B.R. Pratt (Eds.), Carbonate Platforms. Special Publication of the International Association of Sedimentologists. 23, 311-333. doi: 10.1002/ 9781444304114.ch10

Calvet, F., March, M., \& Pedrosa, A. (1987). Estratigrafia, sedimentologia y diagénesis del Muschelkalk superior de los Catalánides. Cuadernos de Geologia Ibérica, 11, 171-197.

Calvet, F., Tucker, M.E., \& Henton, J. (1990). Middle Triassic carbonate ramp systems in the Catalan Basin, northeast Spain: facies, sequences and controls. In: M.E. Tucker, J.L. Wilson \& P.D. Crevello (eds.), Carbonate Platforms: Facies, Sequences and Evolution. Special Publication of the International Association of Sedimentologists, 9, 79-107.

Calzada, S., \& Mañé, R. (1993). Primera cita de un Tilacocéfalo (Crustacea) en el Ladiniense español. Trabajos del Museo Geológico del Seminario de Barcelona, 224, 13-17.

Cartanyà, J. (1999). An overview of the Middle Triassic actinopterygians from Alcover, Mont-ral and El Pinetell (Catalonia, Spain). In G. Arratia \& H.-P. Schultze (Eds.), Mesozoic Fishes 2 - Systematics and Fossil Record, pp. 535-551. München: Pfeil.

Cartanyà, J., Fortuny, J., Bolet, A., \& Mutter, R.J. (2015). Colobodus giganteus (Beltan, 1972) comb. nov. from the Upper Muschelkalk facies of Catalonia (NE Iberian Peninsula). Neues Jahrbuch für Geologie und Paläontologie. Abhandlungen, 278(3), 323-333. doi: $10.1127 /$ njgpa/2015/0532

Cope, E.D. (1887). Zittel's Manual of Palaeontology. American Naturalist, 21, 1014-1019.

De Alessandri, G. (1910). Studi sui pesci triasici della Lombardia. Memorie della Società Italiana di Scienze Naturali e del Museo Civico di Storia Naturale di Milano, 7(1), 1-145.

Fortuny, J., Bolet, A., Sellés, A.G., Cartanyà, J., \& Galobart, À. (2011). New insights on the Permian and Triassic vertebrates from the Iberian Peninsula with emphasis on the Pyrenean and Catalonian basins. Journal of Iberian Geology, 37(1), 67-88.

GARDINER, B.G. (1967). Further notes on paleoniscoid fishes with a classification of the Chondrostei. Bulletin 
of the British Museum (Natural History). Geology, 14, 143-206.

Gardiner, B.G. (1988). A new Cleithrolepis from the Triassic of central Cyrenaica, northeast Libya. In I.A. ELArnaut, ... (Eds.), Subsurface Palynostratigraphy of Northeast Libya (pp. 259-265).

Gardiner, B.G., \& Schaeffer, B. (1989). Interrelationships of lower actinopterygian fishes. Zoological Journal of the Linnean Society, 97(2), 135-187. doi: 10.1111/ j.1096-3642.1989.tb00550.x

Griffith, J. (1977). The Upper Triassic fishes from Polzberg bei Lunz, Austria. Zoological Journal of the Linnean Society, 60(1), 1-93. doi: 10.1111/ j.1096-3642.1977.tb00834.x

Guimerá, J. (1984). Paleogen evolution of deformation in the northeastern Iberian Peninsula. Geological Magazine, 121(05), 413-420. doi: 10.1017/ S0016756800029940

GuimerÀ, J. (1988). Estudi estructural de l'enllaç entre la Serralada Ibérica i la Serralada Costanera Catalana. Doctoral thesis, Universitat de Barcelona, $600 \mathrm{pp}$.

Hutchinson, P. (1973). A revision of the Reedfieldiforn and Perleidiform fishes from the Triassic of Bekker's Kraal (South Africa) and Brookvale (New South Wales). Bulletin of the British Museum (Natural History). Geology, 22(3), 235-354.

Llopis Lladó, N. (1947). Contribución al conocimiento de la morfoestructura de los Catalanides. Publicaciones del Instituto Lucas Mallada de Investigaciones Geológicas del CSIC.

LOMBARDO, C. (1997). Ittiofauna della Kalkschieferzone (Calcare di Meride, Ladinico superiore). Doctoral thesis, Universita' Degli Studi di Milano, Dipartamento di Scienze della Terra, $199 \mathrm{pp}$.

Lombardo, C. (2001). Actinopterygians from the Middle Triassic of northern Italy and Canton Ticino (Switzerland): Anatomical descriptions and nomenclatural problems. Rivista Italiana di Paleontologia e Stratigrafia, 107(3), 345-369.

Lombardo, C., \& Brambillasca, F. (2005). A new perleidiform (Actinopterygii, Osteichthyes) from the Late Triassic of Northern Italy. Bollettino della Società Paleontologica Italiana, 44(1), 25-34.

Lombardo, C., Rusconi, M., \& Tintori, A. (2008). New perleidiform from the Lower Ladinian (Middle Triassic) of the northern Grigna (Northern Italy). Rivista Italiana di Paleontologia e Stratigrafia, 114(2), 263-272.

López-Arbarello, A., \& ZAVATtieri, A.M. (2008). Systematic revision of Pseudobeaconia Bordas, 1944, and Mendocinichthys Whitley, 1953 (actinopterygii: "Perlediformes") from the Triassic of Argentina. Palaeontology, 51(5), 1025-1052. doi: 10.1111/ j.1475-4983.2008.00806.x

López-Gómez, J., Arche, A., \& Pérez-López, A. (2002). Permian and Triassic. In W. GibBons \& T. Moreno (Eds.), The Geology of Spain, pp. 185-212. London: Geological Society Publishing House. doi: 10.1144/ GOSPP.10

MalladA, L. (1889). Reconocimiento geográfico y geológico de la província de Tarragona. Boletín y Comunicaciones del Mapa Geológico de España, 16, 175 pp.
Marquez, A. (1983). Bivalvos del Triásico medio del Sector Meridional de la Cordillera Ibérica y de los Catalánides. Doctoral thesis, Universitat de València, 429 pp.

Mercedes-Martín, R., Salas, R., \& Arenas, C. (2013). Facies heterogeneity and depositional models of a Ladinian (Middle Triassic) microbial-dominated carbonate ramp system (Catalan Coastal ranges, NE Spain). Marine and Petroleum Geology, 46, 107-128. doi: 10.1016/ j.marpetgeo.2013.06.004

Mirabal, R. (1998). La fauna triàsica del jaciment de Móra d'Ebre. Miscellània del CERE, 12, 69-91.

Mutter, R.J. (2002). Revision of the Triassic Family Colobodontidae sensu Andersson 1916 (emended) with a tentative assessment of perleidiform interrelationships (Actinopterygii: Perleidiformes). Doctoral thesis, Universität Zürich, Switzerland, 335 pp.

Mutter, R.J. (2004). The "perleidiform" family colobodontidae: A review. In G. Arratia \& A. Tintori (Eds.), Mesozoic Fishes 3 - Systematics, Paleoenvironments and Biodiversity, pp. 197-208. München: Pfeil.

Mutter, R.J., \& Herzog, A. (2004). A new genus of Triassic actinopterygian with an evaluation of deepened flank scales in fusiform fossil fishes. Journal of Vertebrate Paleontology, 24(4), 794-801. doi: 10.1671/ 0272-4634(2004)024[0794:ANGOTA]2.0.CO;2

Neumayr, M. (1868). Versteinerungen der spanischen Trias in der Verneuilschen Sammlung. Verhandlungen der Kaiserlich-Königlichen Geologischen Reichsanstalt Wien, 1868, 348-349.

Robles, S., \& Iniesta, J. (1977). Pliegues superpuestos en el Mesozoico de la Sierra de la vall de la Torre (Tarragona) y su relación con desgarres regionales del zócalo transversales a la orientación catalánide. Acta Geológica Hispánica, 12, 18-22.

Rusconi, M.R., Lombardo, C., \& Tintori, A. (2007). Colobodontidae from the Upper Triassic (Carnian) of Friuli Venezia (Udine, NE Italy). Gortania, 28, 59-72.

SchaEfFER, B. (1956). Evolution in the subholostean fishes. Evolution; International Journal of Organic Evolution, 10(2), 201-212. doi: 10.1111/ j.1558-5646.1956.tb02845.x

Sun, Z., Lombardo, C., Tintori, A., \& Jiang, D. (2015). A new species of Altisolepis (Peltopleuriformes, Actinopterygii) from the Middle Triassic of southern China. Journal of Vertebrate Paleontology, 35(2), e909819. doi: 10.1080/02724634.2014.909819

Sun, Z., Lombardo, C., Tintori, A., JiAng, D.-Y., Hao, W-C., Sun, Y-L., \& LiN, H.Q. (2012). Fuyuanperleidus dengi Geng etal., 2012 (Ostheichthyes, Actinopterygii) from the middle Triassic of Yunnan Province, South China. Rivista Italiana di Paleontologia e Stratigrafia, 118 (3), 359-373.

Sun, Z., Tintori, A., Jiang, D., \& Motani, R. (2013). A new perleidid from the Spathian (Olenekian, Early Triassic) of Chaohu, Anhui Province, China. Rivista Italiana di Paleontologia e Stratigrafia, 119(3), 275-285.

Teixell, A. (1986). Estudi geològic de les serres de Pàndols, Cavalls i del Montsant i les seves relacions amb les depressions de l'Ebre i de Móra (Tarragona). Tesi de llicenciatura, Universitat de Barcelona, 149 pp. 
Tintori, A. (1990). Dipteronotus olgiatti n. sp. (Actinopterygii, Perleidiformes) from the Kalkschieferzone of Ca'del Frate (N. Italy). Atti Ticinesi di Scientia della Terra, 33, 191-197.

Tintori, A. (1998). Ctenognathichthys bellotti (De AlesSANDRI, 1910): Nomenclatural problems and stratigraphical importance of this Middle Triassic actinopterygian fish. Rivista Italiana di Paleontologia e Stratigrafia, 104(2), 417-422.

Tintori, A., \& Lombardo, C. (1996). Gabanellia agilis gen. n. sp. n. (Actinopterygii, Perleidiformes) from the calcare di Zorzino of Lombardy (North Italy). Rivista Italiana di Paleontologia e Stratigrafia, 102(2), 227-236.

DE Verneuil, E. (1854). Descubrimiento de Ceratites en Mora de Ebro. Reviews in Mineralogy, 5, 676-677.

Via-Boada, L., Villalta, J.F., \& Esteban, M. (1977). Paleontologia y paleoecologia de los yacimientos fosilíferos del Muschelkalk superior entre Alcover y Montral (Montañas de Prades, Provincia de Tarragona). Cuadernos de Geologia Ibérica, 4, 247-256.

Virgili, C. (1958). El Triásico de los Catalánides. Boletín del Instituto Geológico y Minero de España, 69, 1-856.

WadE, R.-T. (1935). The Triassic fishes of Brookvale, New South Wales. xiv+89 pp.; London (British Museum, Natural History).

Xu, G.H., GaO, K.-Q., \& Coates, M.I. (2015). Taxonomic revision of Plesiofuro mingshuica from the Lower Triassic of northern Gansu, China, and the relationships of early neopterygian clades. Journal of Vertebrate Paleontology, 35(6), e1001515. doi: 10.1080/ 02724634.2014.1001515

Manuscript received: October 22nd, 2017.

Revised version accepted by the Stuttgart editor: January 17 th, 2019.

\section{Addresses of the authors:}

Joan Cartanyà, Institut Català de Paleontologia M. Crusafont, Z building, Universitat Autònoma de Barcelona, CP: 08193 Cerdanyola del Vallès, Barcelona, Spain \& Centre d'Història Natural de la Conca de Barberà C/ Pedrera, 2 - 43400 Montblanc, Tarragona, Spain

e-mail: joan.cartanya@icp.cat

Josep Fortuny, Institut Català de Paleontologia M. Crusafont, Z building, Universitat Autònoma de Barcelona, CP: 08193 Cerdanyola del Vallès, Barcelona, Spain \& Centre de Recherches en Paléobiodiversité et Paléoenvironnements, Muséum National d'Histoire Naturelle, Bâtiment de Paléontologie, CP38, 8 rue Buffon, 75005 Paris, France.

Arnau Bolet, Institut Català de Paleontologia M. Crusafont, Z building, Universitat Autònoma de Barcelona, CP: 08193 Cerdanyola del Vallès, Barcelona, Spain \& School of Earth Sciences, University of Bristol, Life Sciences Building, 24 Tyndall Avenue, Bristol BS81TQ, UK.

Ruben Garcia-Artigas, Institut Català de Paleontologia M. Crusafont, Z building, Universitat Autònoma de Barcelona, CP: 08193 Cerdanyola del Vallès, Barcelona, Spain \& Departament de Mineralogia, Petrologia i Geologia Aplicada, Facultat de Ciències de la Terra, Universitat de Barcelona, C/Martí i Franquès s/n, 08030 Barcelona, Spain; and Institut de Recerca de l'Aigua, Facultat de Geografia i Història, Universitat de Barcelona, C/Montalegre, 6, 08001 Barcelona, Spain. 